\title{
Conodont biostratigraphy and global correlation of the middle Darriwilian-lower Sandbian (Ordovician) Las Aguaditas Formation, Precordillera of San Juan, Argentina
}

\author{
*Nicolás A. Feltes ${ }^{1}$, Guillermo L. Albanesi' ${ }^{1}$, Stig M. Bergström² \\ 1 CICTERRA (CONICET-UNC), Avda. Vélez Sarsfield 1611, X5016GCA, Córdoba, Argentina. \\ nfeltes@efn.uncor.edu; guillermo.albanesi@unc.edu.ar \\ 2 School of Earth Sciences, Division of Historical Geology, The Ohio State University, 125 South Oval Mall, Columbus OH 43210, USA. \\ stig@geology.ohio-state.edu \\ * Corresponding author: nfeltes@efn.uncor.edu
}

\begin{abstract}
Middle Darriwilian to lower Sandbian conodonts were recorded from the Las Aguaditas Formation at its type section in the Argentine Precordillera. A total of 9,974 conodont specimens were recovered from 46 carbonate samples, which represent 68 species of 38 genera. A biostratigraphic study verified a middle Darriwilian age for the interval spanning the contact between the San Juan and the Las Aguaditas formations. The following zones are determined in the study section: the Lenodus variabilis Zone, with the Periodon gladysae and Paroistodus horridus subzones following the Precordilleran scheme; the L. variabilis, Yangtzeplacognathus crassus, and the Eoplacognathus pseudoplanus zones with the Microzarkodina hagetiana and M. ozarkodella subzones, and the Pygodus anserinus Zone, according to the Scandinavian scheme; the Periodon macrodentatus Zone, with the Histiodella sinuosa, H. holodentata and $H$. cf. holodentata subzones, and the P. zgierzensis Zone with the H. kristinae Subzone that correlates the North American scheme. A stratigraphic gap was recognized between the lower and middle members of the Las Aguaditas Formation. It comprises the Eoplacognathus suecicus and Pygodus serra zones, and the lower subzone of the Pygodus anserinus Zone. The variation of conodont diversity through the study section conforms to shallowing and deepening patterns, which accompanies the changes of the provenance lithology. Three conodont assemblages were quantitatively recognized: a) Diverse conodont association, b) Low diversity conodont association and c) Recovery phase association. We propose to use the North American biozonal scheme of conodonts for the Central Precordillera because of the affinity of documented index taxa, which provides a more accurate intercontinental correlation for the global Middle Ordovician Series.
\end{abstract}

Keywords: Conodont, Darriwilian-Sandbian, Biostratigraphy, Paleoecology, Precordillera, Argentina.

RESUMEN. Bioestratigrafía de conodontes y correlación global del Darriwiliano medio-Sandbiano inferior (Ordovícico) Formación Las Aguaditas, precordillera de San Juan, Argentina. En la Formación Las Aguaditas, en su sección tipo en la precordillera Argentina, se registraron conodontes del Darriwiliano medio al Sandbiano bajo. Se recuperaron un total de 9.974 especímenes de 46 muestras carbonáticas; estos representan 68 especies pertenecientes a 38 géneros. Se llevó a cabo un estudio bioestratigráfico para verificar la edad del intervalo que incluye el contacto entra las formaciones San Juan y Las Aguaditas. La presencia de taxones guía indican una edad darriwiliana media para este intervalo. Las siguientes biozonas fueron determinadas en el área de estudio: Zona de Lenodus variabilis, con las subzonas de Periodon gladysae y Paroistodus horridus, correspondientes al esquema establecido para la precordillera; las zonas de L. variabilis, Yangtzeplacognathus crassus y la de Eoplacognathus pseudoplanus con la subzonas de Microzarkodina hagetiana y M. ozarkodella, y la Zona de Pygodus anserinus, según el esquema Báltico; la Zona de Periodon macrodentatus, con las subzonas de Histiodella sinuosa, $H$. holodentata y $H$. cf. holodentata, y la Zona de $P$. zgierzensis con la subzona de $H$. kristinae que se correlaciona con el esquema norteamericano. Se reconoció una discontinuidad estratigráfica entre los miembros inferior y medio de la Formación Las Aguaditas. Esta comprende las zonas de Eoplacognathus suecicus y Pygodus serra, y la subzona inferior de la Zona de Pygodus anserinus. La variación en la diversidad de conodontes en la sección de estudio se corresponde con patrones de somerización y profundización, que a su vez son congruentes con los cambios en la litología. Luego de analizar la composición taxonómica de las muestras se reconocieron, de manera cuantitativa, tres asociaciones de conodontes: a) Asociación diversa de conodontes, b) Asociación de baja diversidad de conodontes, y c) Asociación de conodontes en fase de recuperación. Se propone aplicar para la precordillera central el esquema de biozonación de América del Norte debido a la afinidad de los taxones guía documentada, brindando una correlación intercontinental más precisa para el Ordovícico Medio a nivel global. 


\section{Introduction}

The Precordillera of western Argentina is bordered by the Sierras Pampeanas to the east and by the Cordillera Frontal to the west. This geological province which extends $450 \mathrm{~km}$ meridionally and $110 \mathrm{~km}$ from east to west (Fig. 1) is characterized by thick Lower Paleozoic marine units (Furque and Cuerda, 1979). The nature and origin of the Precordillera has been the subject of diverse studies (e.g., Astini et al., 1995; Aceñolaza et al., 2002; Benedetto, 2004; Voldman et al., 2009). It is interpreted as part of a major exotic terrane. The study of Cambrian and Ordovician faunas is crucial to understand the origin, migration and accretion to its present position. Some authors suggest an allochthonous origin for this terrane, with rifting from Laurentia, beginning drift across the Iapetus Ocean in the Cambrian and accretion to the western margin of Gondwana by the Mid or mid-Late Ordovician (Benedetto, 1993; Benedetto et al., 2009; Astini et al., 1995; Bordonaro and Banchig, 1995; Albanesi et al., 1995a; Albanesi and Bergström, 2010). An alternative hypothesis considers the Precordillera a para-autochthonous Gondwanan block, which drifted along the Gondwana margin from its original position close to Antarctica and South Africa (Aceñolaza et al., 2002; Finney, 2007).

The stratigraphy of the Precordillera is characterized by a 2,300 $\mathrm{m}$ thick succession of Cambro-Ordovician limestones, which were deposited on a continental shelf to the east and interdigitate with clastic slope deposits toward the west (Keller et al., 1993; Astini, 1995). This supports the allochthonous hypothesis, due to the fact that deposits of limestones of such a great thickness could only be expected in warm seas, at lower latitudes than the position of Gondwana at that time (Benedetto, 2010). The Precordillera is the only South American Lower Paleozoic basin with a carbonate platform, representing depositional environments from shallow intertidal settings to marginal shelf or deep ramp settings (Cañas, 1999). The shelf experienced a rapid sea level rise to the east, which led to the drowning of the platform. This event interrupted the carbonate production and resulted in the widespread deposition of graptolitic black shales (e.g., Gualcamayo and Los Azules formations). The Las Chacritas, Sassito and Las Aguaditas formations are the only remnants of carbonate deposits in the entire Precordillera after the Cambro-Ordovician carbonate cycle, and the

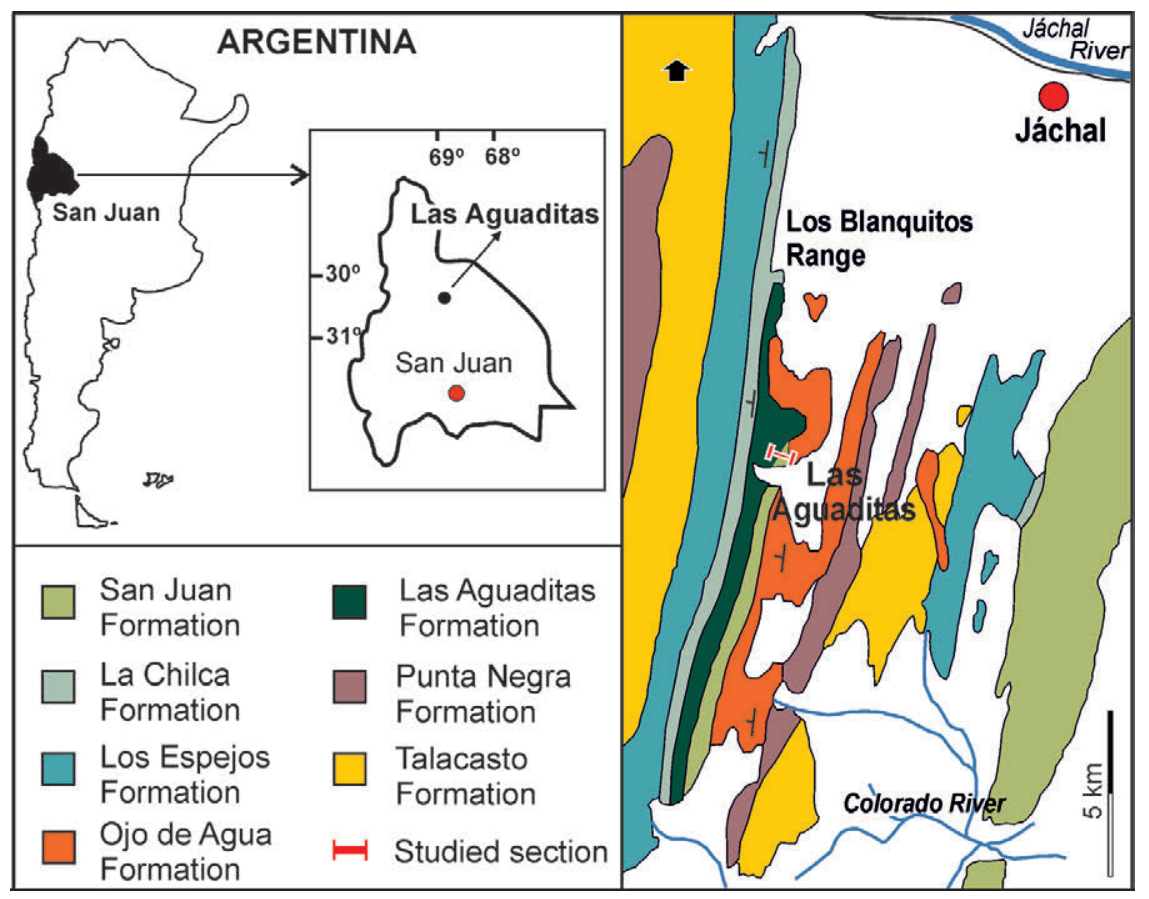

FIG. 1. Geologic map and location of the Las Aguaditas Creek section in the Los Blanquitos Range, Precordillera of San Juan, Argentina. 
Las Aguaditas Formation is the only unit that shows a transition from a platform to slope depositional environment (Astini, 1995; Keller et al., 1993).

Establishing an accurate biostratigraphy for the upper part of the San Juan Formation and the lower member of the Las Aguaditas Formation is necessary for determining with precision the deepening event that affected the whole Precordillera. Although some previous conodont studies have been carried out on the Las Aguaditas Formation at its type section (Eberlein, 1990; Keller et al., 1993), the present contribution is based on detailed sampling, which allow us to recognize a hiatus between the lower and the middle members of the Las Aguaditas Formation. Also, a detailed biostratigraphic scheme for the middle Darriwilian to Lower Sandbian interval of the Argentine Precordillera is presented based on new conodont data from this section, which allows a precise correlation at the regional and global level. Moreover, the biogeographic affinity of the conodont associations recognized through the stratigraphic range is investigated, and compared with those of Laurentian, Baltoscandian, and Gondwanan localities to contribute to a better understanding of the position of the Precordillera during this time span.

\section{Las Aguaditas Formation}

The type section of the Las Aguaditas Formation is on the eastern flank of the Los Blanquitos Range, in the Central Precordillera of San Juan Province, $10 \mathrm{~km}$ to the southwest of Jachal City (Keller et al., 1993). Baldis and Blasco (1974) recognized four members in their original stratigraphic description of the unit, namely a $54 \mathrm{~m}$ thick lower member; a $110 \mathrm{~m}$ thick slaty member; a $40 \mathrm{~m}$ thick middle member; and an $80 \mathrm{~m}$ thick upper member. Later, it was formally defined by Baldis et al. (1982) at its type section. Lithologically, the formation consists of marls, limestones, and reef limestones, with a characteristic yellowish weathering color. This formation overlies paraconformably the San Juan Formation (Astini, 1995), which is easily distinguished by its nodular limestones (Baldis et al., 1982), with the contact marked by a regional hardground surface (Astini, 1995). Baldis and Blasco (1974) recognized a stratigraphic gap between the upper member of the Las Aguaditas Formation and the overlying La Chilca Formation of latest Ordovician to earliest Silurian age.
Astini (1995) distinguished three transgressive and regressive cycles in the whole formation. This author also described two types of facies associations that replace each other through the formation, a distal ramp to slope-basin facies transition, and an upper to middle slope facies. The Las Aguaditas Formation is interpreted as deposited on structural elevations (horsts) within the basin (Astini, 1995, 1997).

The top part of the San Juan Formation represents a distal ramp environment with minor storm influence. The transition interval between the latter unit and the overlying Las Aguaditas Formation includes calcareous-pelitic deposits, whose depositional regime is interpreted to be caused by a flooding event on the platform, since there is no evidence of a stratigraphic gap at the contact (Keller et al., 1993; Carrera and Astini, 1998). This local event led to a facies change with the deposition of hemipelagic limestones at the transition to the Las Aguaditas Formation (Keller et al. 1993). It may coincide with a sea level rise caused by a rapid warming after the cooling peak reached during the middle Darriwilian (Webby, 1984), which caused the deposition of black shales and mudstones (Fortey, 1984). The environmental change recognizable in the lithology is associated by a remarkable faunal turnover between the San Juan and the Las Aguaditas formations. Porifera remnants are common in the top part of the former unit, while bryozoans dominate the Las Aguaditas Formation (Carrera, 1997; Carrera and Ernst, 2010). This change could be caused by local and global changes adverse for sponges but favorable for bryozoans, such as an increase in nutrients and turbidity that restricts the development of the carbonate platform (Wood, 1993). This condition is supported by the record of K-bentonite levels in the transition between the San Juan and the overlying units (Huff et al., 1997). Another possible cause is a decrease in the sea water temperature as a consequence of the migration of the Precordillera to higher latitudes and a sea level rise of global scale (Astini, 1995; Webby et al., 2004).

The shallow outer-shelf strata represented by the San Juan Formation and those of the deeper water environment represented by the lower member of the Las Aguaditas Formation exhibit a high diversity of conodonts. Albanesi et al. (2006) explain that this is probably due to nutrient enrichment as a product of upwelling currents, as well as to a shallow-deep water faunal exchange through the thermocline. 


\subsection{Previous conodont biostratigraphic studies}

The lower member of the Las Aguaditas Formation correlates with several formations in the Precordillera, such as the lower member of the Gualcamayo Formation (Albanesi et al., 1998; Astini, 1995), the lower member of the Los Azules Formation (Ortega et al., 2007), the Las Chacritas Formation (Serra et $a l ., 2015)$, with the lower Sierra de la Invernada Formation (Albanesi et al., 2009) and the Yerba Loca Formation at the Ancaucha Creek (Albanesi et al., 1995b; Voldman et al., 2008).

The first conodont biostratigraphic dating proposed a Floian age for the top part of the San Juan Formation at the Las Aguaditas creek section (Sarmiento et al., 1986). Albanesi et al. (1998) reviewed this interval and referred it to the middle Darriwilian based on the identification of the Lenodus variabilis Zone. More recently, Feltes et al. (2014) recognized the Yangtzeplacognathus crassus Zone, based on the identification of the eponymous index species, in the contact interval between the San Juan and the Las Aguaditas formations at the Las Aguaditas Creek section.

The index conodont Pygodus serra was reported by Keller et al. (1993) above the lower member of the Las Aguaditas Formation, indicating a late Darriwilian age for most of the unit. Eberlein (1990) and Lehnert (1995) recognized the P. serra and $P$. anserinus zones in the middle and upper parts of the Las Aguaditas Formation. In the upper portion of the formation Albanesi and Ortega (1998) identified the conodont index species of the lower Sandbian Amorphognathus tvaerensis in association with Baltoniodus variabilis, Baltoniodus gerdae and Cahabagnathus sweeti (cf. Lehnert et al., 1999). Recently, Serra et al. (2013) confirmed the presence of $P$. anserinus from the base of the middle member to the top of the upper member of the Las Aguaditas Formation.

\section{Materials and Methods}

Over $66 \mathrm{~kg}$ of rocks were processed, which correspond to 46 carbonate samples from the upper part of the San Juan Formation and the lower member, and base of the middle member, of the Las Aguaditas Formation. A total of 9,974 conodont specimens have been recovered, which represent 68 species that belong to 38 genera (Fig. 2).
Our statistical analysis is based on the frequency of conodont genera in each sample. Patzkowsky (1995) considered that the identification of genera rather than species gives more reliable results and the former represents a longer time span permitting environmental association of fossil taxa to be more easily identified. Only samples with more than 2 genera were included in the analysis and taxa that occurred in only one sample were excluded. This produced a final data matrix consisting of 25 samples and 32 genera. Conodont associations were identified quantitatively on the basis of Q-mode cluster analysis of samples based on the unweighted pair group method using arithmetic averages (UPGMA) and the Bray-Curtis similarity coefficient. Raw counts were logarithmically (ln) transformed.

Hierarchical cluster analysis was performed using PAST 2.15 (Hammer et al., 2001). The abundance pattern was analyzed using the Inkspot tool in R 3.1.2 from the rioja package (Juggins, 2015).

The conodont elements have a color alteration index (CAI) of 3, which indicates paleotemperatures ranging from $110^{\circ}$ to $190^{\circ} \mathrm{C}$ (Epstein et al., 1977). The specimens recorded from the San Juan Formation and the uppermost part of the lower member of the Las Aguaditas Formation are abundant, well preserved and taxonomically diverse, whereas the specimens recovered from the basal parts of the lower and middle members of the Las Aguaditas Formation are scarce, and their preservation is poor. The fossil collection is housed in the Museo de Paleontología, FCEFyN, UNC, under repository code CORD-MP.

\section{Conodont biostratigraphy}

The first formal conodont-graptolite biostratigraphic scheme for the middle Darriwilian of the Precordillera was published by Albanesi et al. (1995b, 1998) and later revised by Albanesi and Ortega (2002). The conodont zonal units included the Lenodus variabilis Zone with the Periodon gladysae and Paroistodus horridus subzones, and the Eoplacognathus suecicus Zone, with the Histiodella kristinae and Pygodus anitae subzones.

Based on the conodont index species identified in the study section, the middle Darriwilian conodont zones proposed in Scandinavia can be recognized. These comprise the Lenodus variabilis, Yangtzeplacognathus crassus, and Eoplacognathus pseudoplanus zones, and the M. hagetiana and 


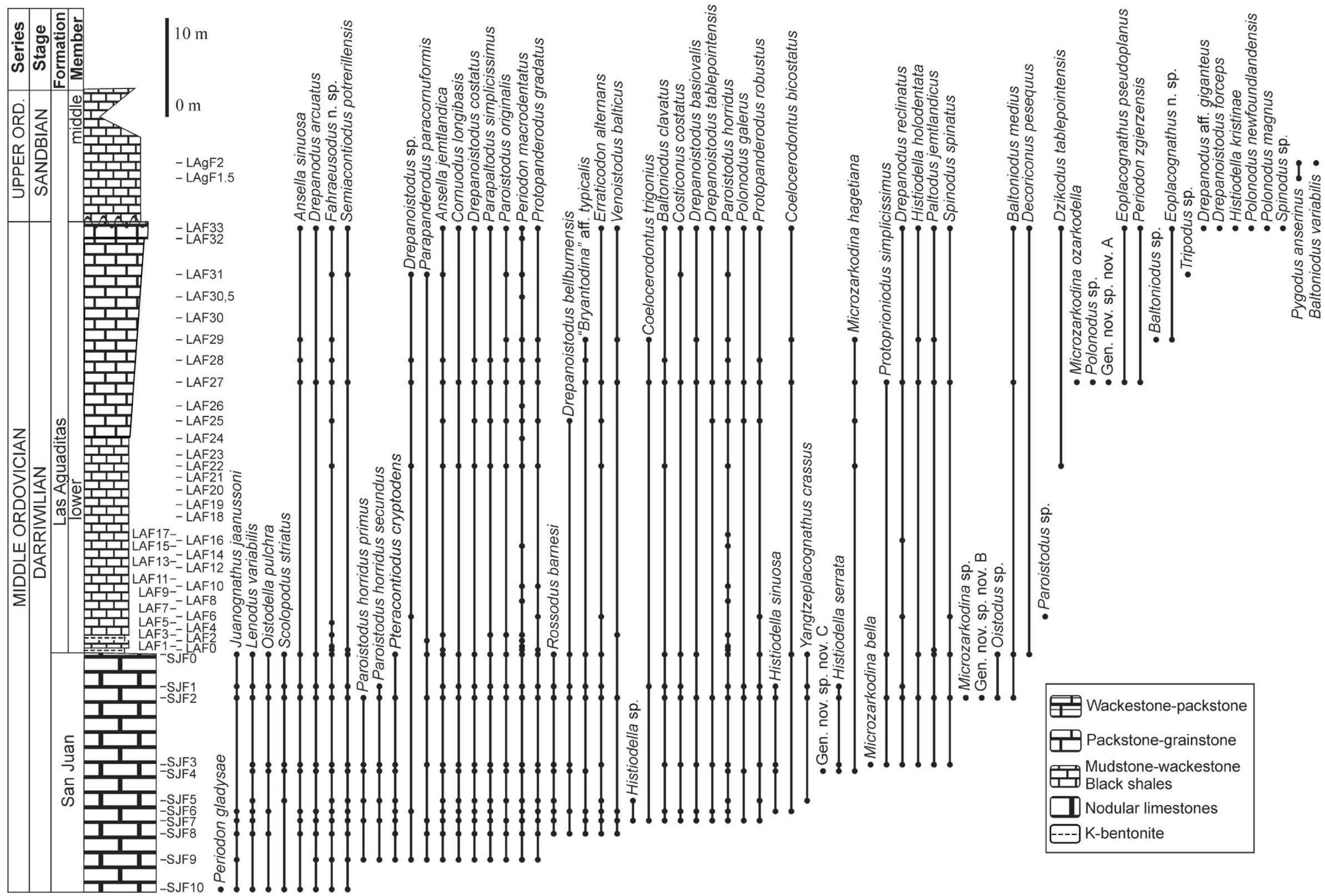


M. ozarkodella subzones of the latter zone. It was also possible to recognize the lineage zones of the same time span proposed for North America that consists of the Periodon macrodentatus Zone with its Histiodella sinuosa and Histiodella holodentata subzones and the Periodon zgierzensis Zone, Histiodella kristinae Subzone (Fig. 3). Additionally, the Lenodus variabilis Zone with its Periodon gladysae and Paroistodus horridus subzones which were proposed by Albanesi and Ortega (2002) for the Precordillera, were also identified, following the emendation by Carrera et al. (2013). The uppermost biozone identified in the studied section is the upper subzone of the Pygodus anserinus Zone, of Sandbian age (Fig. 4), although the recorded presence of Amorphognathus tvaerensis at the top of the section cannot be discarded based on our current records.

\subsection{Lenodus variabilis Zone}

In our study interval, the lower Darriwilian conodont zonation begins with the FAD of Lenodus variabilis (in the stratigraphic lowest sample SJF10), using the Scandinavian scheme. This sample was taken from the lowest visible stratum in the study section, in the upper part of the San Juan Formation, $24 \mathrm{~m}$ below the contact with the overlying Las Aguaditas Formation. In this sample Periodon gladysae was also identified, indicating the Periodon gladysae Subzone of the Lenodus variabilis Zone. The $\mathrm{M}$ element of $L$. variabilis was identified, which according to Löfgren and Zhang (2003) is the diagnostic morphotype of the species. In sample SJF7, ca. $7 \mathrm{~m}$ above SJF10, Pa elements of $L$. variabilis were recovered confirming its presence. Sample SJF9 carries elements of $P$. horridus primus and $P$. horridus secundus, which indicate the $P$. horridus Subzone of the $L$. variabilis Zone defined by Albanesi and Ortega (2002) for regional correlation, and recently well documented by Carrera et al. (2013), following this concept. The upper boundary of this zone is defined by the FAD of $P$. h. horridus that indicates the beginning of the Yangtzeplacognathus crassus Zone at $17 \mathrm{~m}$ below the base of the Las Aguaditas Formation (SJF7). This biozone is $7 \mathrm{~m}$ thick at the study section.

The Periodon gladysae Subzone is characterized by the presence of several species associated with the index species, such as Ansella sinuosa, Juanognathus jaanussoni, and Semiacontiodus potrerillensis. In the Paroistodus horridus Subzone, the biodiversity increases greatly, with the presence of Ansella jemtlandica, Baltoniodus clavatus, Cornuodus longibasis, Drepanoistodus basiovalis, Drepanoistodus costatus, Erraticodon alternans, Parapaltodus simplicissimus, Parapanderodus paracornuformis, Periodon macrodentatus, Pteracontiodus cryptodens, Rossodus barnesi, Paroistodus originalis, Paroistodus horridus primus and P. h. secundus (Table 1). In Paroistodus the speciation process documented by Albanesi and Barnes (2000) occurs in the studied section between samples SJF9 and SJF0. In the oldest sample, the ancestor $P$. originalis was recovered along with the intermediate forms, Paroistodus h. primus and Paroistodus $h$. secundus, and $4 \mathrm{~m}$ higher (SJF7) the derived species, $P$. h. horridus, makes its entrance in lower frequency than the older species. In the interval of the samples SJF6 to SJF2, P. horridus tends to increase in relative abundance until Paroistodus h. primus and Paroistodus h. secundus disappear in samples SJF1 and SJF0, respectively. Above SJF0, only P. horridus was recovered and extends to the top of the lower member of the Las Aguaditas Formation. These records allow for a precise correlation at regional level, where this speciation event may have occurred.

\subsubsection{Regional and global correlation}

The conodont species $L$. variabilis has previously been reported from the San Juan and Gualcamayo formations in the Villicum Range (Sarmiento, 1985; Heredia and Mestre, 2013a,b; Mestre, 2013), and at Cerro Viejo of Huaco (Ottone et al., 1999; Ortega et al., 2007), in the uppermost part of the San Juan Formation at Portezuelo de Yanzo and Cerro Potrerillo (Ortega et al., 1995; Albanesi et al., 1998; Albanesi and Ortega, 2002), and also in the Yerba Loca Formation from the western Precordillera (Albanesi et al., 1995b).

The Lenodus variabilis Zone of the Las Aguaditas Formation correlates with coeval strata of other regions such as the St. Petersburg area in Russia where it was originally described by Sergeeva (1963), and in central and southern Estonia (Viira, 1974), Sweden (Löfgren, 1978; Stouge and Bagnoli, 1999; Löfgren, 2000; Mellgren and Eriksson, 2009), and elsewhere in Baltoscandia. In south-central China this index taxon was identified at the Yangtze Valley (Ni and Li, 1987; Zhang, 1998a; Wang and Bergström, 1999). 


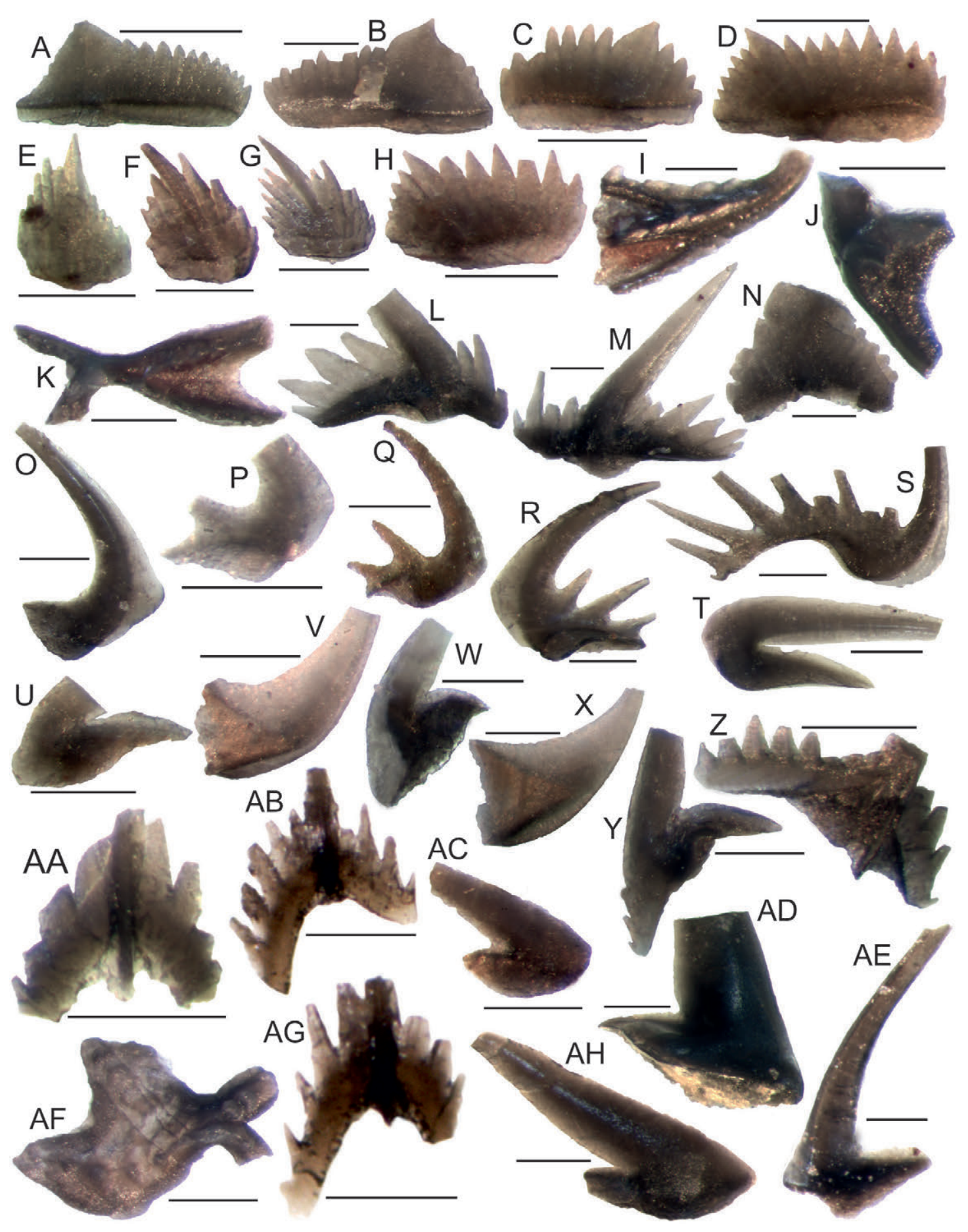




\subsection{Yangtzeplacognathus crassus Zone}

The Yangtzeplacognathus crassus Zone overlies the $L$. variabilis Zone in the studied section. The index taxon $Y$. crassus was identified in sample SJF5, from $15 \mathrm{~m}$ below the contact with the Las Aguaditas Formation. However, the lower boundary of this biozone is marked by the presence of $P$. $h$. horridus, which appears $17 \mathrm{~m}$ below the top of the San Juan Formation (SJF7). The upper boundary is determined by the FAD of Dzikodus tablepointensis at level LAF22, $19 \mathrm{~m}$ above the base of the Las Aguaditas Formation, which indicates the beginning of the Eoplacognathus pseudoplanus Zone. The Y. crassus Zone is $36 \mathrm{~m}$ thick at the Las Aguaditas type section. The index species $Y$. crassus was identified on the basis of several elements of its multielemental apparatus, including $\mathrm{Pa}$ elements that are diagnostic at the species level. Although the morphotypes $\mathrm{Pa}$ and $\mathrm{Pb}$ change considerably through the ontogeny (Zhang, 1997), their range barely overlaps with that of Lenodus at our study section. This is similar to their occurrences in Swedish and southern Chinese sections, as shown by Löfgren and Zhang (2003).

A total of 52 conodont species were identified within the interval of this zone. Apart from the index species, the more abundant are $A$. jemtlandica, A. sinuosa, D. basiovalis, D. bellburnensis, D. tablepointensis, Fahraeusodus n. sp., H. holodentata, H. sinuosa, $P$. simplicissimus, P. horridus, P. originalis, P. macrodentatus, P. gradatus, Pteracontiodus cryptodens, R. barnesi and Semiacontiodus potrerillensis. Other associated taxa are less abundant, such as
B. clavatus, B. medius, $C$. longibasis, $C$. costatus, $D$. arcuatus, E. alternans, Oistodella pulchra, Paltodus jemtlandicus, $P$. horridus primus, $P$. h. secundus, Polonodus galerus, P. robustus, Protoprioniodus simplicissimus and Scolopodus striatus (Table 1). The record of $B$. medius in sample SJF2 verifies the biostratigraphic definition of Albanesi (1998), who indicates that the lower boundary of the P. horridus Subzone of the $L$. variabilis Zone coincides with the presence of the latter zone index species.

This zone includes the transition interval between the San Juan Formation and the overlying Las Aguaditas Formation. The latter formation begins with a change in lithology that shows a deepening of the basin. The samples from the lower part of the lower member are virtually barren of conodonts, with many yielding pyrite cubes indicating an anoxic paleoenvironment, up to the level of LAF22 where the fauna began to recover. It is worth noting that in samples LAF2, LAF6, LAF12 and LAF24 fossil metallic spherullites were recovered. These levels, except for sample LAF24, span the coeval interval as occurs at Kinnekulle, Sweden, where micrometeorites were found (Schmitz et al., 2003, 2008; Mellgren and Eriksson, 2009).

\subsubsection{Regional and global correlation}

Huff et al. (1997) dated the top part of the San Juan Formation and lower part of the Los Azules Formation at Cerro Viejo of Huaco, using the U-Pb method on zircons present in the K-bentonites, as $464 \pm 2 \mathrm{Ma}$, which provides an absolute dating of the $Y$. crassus Zone. This interval correlates with the

FIG. 3. Scale bar 0,2 mm. A. Histiodella sinuosa Graves and Ellison, Pa, SJF3, CORD-MP 34948; B. Histiodella serrata Harris, Pa, SJF3, CORD-MP 35043; C, E-G. Histiodella holodentata Ethington and Clark; C. Pa, SJF3, CORD-MP 35077; E. Pb?, LAF33, CORD-MP 35190; F. Sc, LAF33, CORD-MP 35191; G. Sc, LAF33, CORD-MP 35192; D. Histiodella cf. holodentata Stouge, Pa, LAF33, CORD-MP 20579; H. Histiodella kristinae Stouge, Pa, LAF33, CORD-MP 35193; I-K. Lenodus variabilis (Sergeeva); I. Sb, SJF6, CORD-MP 35312; J. M, SJF6, CORD-MP 35269; K. Pa, SJF6, CORD-MP 35280; L. Periodon macrodentatus (Graves and Ellison), Pa, LAF33, CORD-MP 36740; M. Periodon zgierzensis Dzik, Pa, LAF33, CORD-MP 38933; N. Periodon gladysae Albanesi, Pa, SJF10, CORD-MP 36736; O. Paroistodus originalis (Sergeeva), Sc, LAF27, CORD-MP 36612; P. Paroistodus horridus primus Albanesi, Sa, SJF5, CORD-MP 35624; Q. Paroistodus horridus secundus Albanesi, Sa, SJF7, CORD-MP 35670; R-T. Paroistodus horridus (Barnes and Poplawski); R. Sc, LAF27, CORD-MP 35900; S. Sb, LAF27, CORD-MP 36300; T. M, LAF27, CORD-MP 35774; U-V. Ansella sinuosa Stouge; U. M, SJF3, CORD-MP 33321; V. Pa, SJF3, CORD-MP 33520; W-X. Ansella jemtlandica (Löfgren); W. M, LAF27, CORD-MP 33000; X. Pa, SJF3, CORD-MP 33320; Y-Z. Baltoniodus clavatus Stouge and Bagnoli; Y. M, SJF3, CORD-MP 33521; Z. Pa, SJF3, CORD-MP 33551; AA. Microzarkodina bella Löfgren, Sa, SJF3, CORD-MP 35314; AB. Microzarkodina hagetiana Stouge and Bagnoli, Sa, LAF27, CORD-MP 21601; AC. Drepanoistodus basiovalis (Sergeeva), M, LAF27, CORD-MP 33901; AD. Drepanoistodus bellburnensis Stouge, M, SJF7, CORD-MP 33946; AE. Pteracontiodus cryptodens (Mound), P, SJF6, CORD-MP 40008; AF. Yangtzeplacognathus crassus (Chen and Zhang), Pa, SJF1, CORD-MP 40721; AG. Microzarkodina ozarkodella Lindström, Sa, LAF27, CORD-MP 25001; AH. Drepanoistodus tablepointensis Stouge, M, LAF33, CORD-MP 34113. 


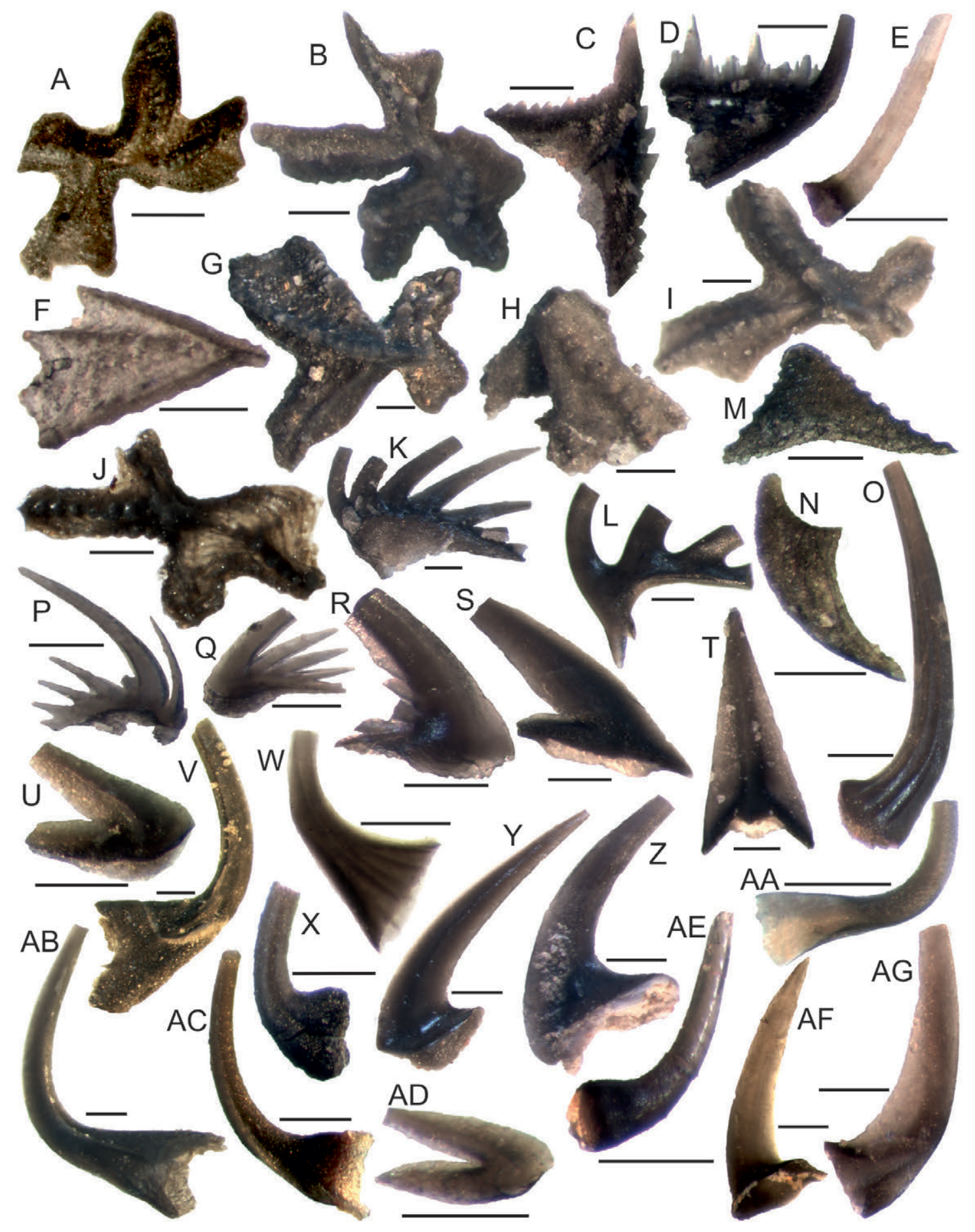


transition from the San Juan Formation to the overlying Las Aguaditas, Las Chacritas, and Gualcamayo formations where the same index species and the $\mathrm{K}$-bentonites beds were identified as well (Heredia et al., 2011; Serra et al., 2011).

The presence of the index taxon, Y. crassus was first recorded in the Precordillera from the upper San Juan Formation (Lehnert, 1995), and subsequently it was found at numerous localities. At a regional level, this zone correlates with coeval strata in the Las Chacritas River section, Villicum range, Cerro Viejo of Huaco and Oculta creek, where the transition from the San Juan Formation to the overlying units occurs in a similar way as in the Las Aguaditas creek section (Albanesi et al., 2013; Feltes et al., 2014; Serra et al., 2015). The fauna associated with $Y$. crassus also allows the correlation with the Yerba Loca Formation at Ancaucha creek (Albanesi et al., 1995b; Voldman et al., 2008) and with the Los Sombreros Formation at Los Túneles of Jáchal river (Voldman et al., 2009).

The presence of $Y$. crassus along with the associated fauna, enables a precise global correlation with stratigraphic successions at several areas of south China, such as Yichang in the Hubei Province (Zhang, 1997), Shitai in the Anhui Province (Chen and Zhang, 1989), and at Kalping in the Xinjiang Province, northwest China (Wang et al., 1996). It also correlates with several areas in Scandinavia, for instance, Kinnekulle and Billingen (Zhang, 1997, 1998b; Mellgren and Eriksson, 2009), Scania (Erlström et al., 2001; Stouge and Nielsen, 2003), Öland (Stouge and Bagnoli, 1999), and in the East
Baltic (Männik and Viira, 2012) among others. In our study section $Y$. crassus appears associated with the uppermost record of $L$. variabilis, as recorded by Löfgren and Zhang (2003) for the Baltic region. However, unlike Scandinavia, it disappears well before the first record of E. pseudoplanus. This may be due to the deepening in this interval, where virtually no conodonts were recovered, except for few species such as Periodon macrodentatus, Paroistodus horridus and Protopanderodus gradatus.

\subsection{Eoplacognathus pseudoplanus Zone}

In the middle part of the lower member of the Las Aguaditas Formation the index taxa E. pseudoplanus and Dzikodus tablepointensis were identified. The latter was documented in sample LAF22, $19 \mathrm{~m}$ above the base of the formation, while E. pseudoplanus was identified in younger strata, in sample LAF27 at 8.5 $\mathrm{m}$ above $D$. tablepointensis. Zhang (1998a) regarded the D. tablepointensis Zone as equivalent to the $E$. pseudoplanus Zone in south-central China. In the Jämtland sections of Sweden, the upper subzone of the E. pseudoplanus Zone contains a great abundance of D. tablepointensis. In our study section, D. tablepointensis appears first in the succession probably due to environmental restrictions for E. pseudoplanus as a consequence of the sudden deepening event in the transition between the San Juan to the Las Aguaditas formations. Dzikodus is more typical of south-central China (Zhang, 1998a) and western Newfoundland (Stouge, 1984) where it occurs in deep water environments (Pyle and Barnes, 2002).

FIG. 4. Scale bar 0,2 mm. A. Eoplacognathus pseudoplanus (Viira), Pa, LAF33, CORD-MP 34394; B. Eoplacognathus n sp., Pa, LAF33, CORD-MP 34383; C-D. Baltoniodus variabilis (Bergström); C. Pa, LAgF2, CORD-MP 44201; D. Sc, LAgF2, CORD-MP 44202; E. Decoriconus pesecuus Löfgren, S, LAF33, CORD-MP 33758; F. Pygodus anserinus Lamont and Lindström, Pa, LAgF1,5, CORD-MP 44100; G-H. Polonodus magnus Albanesi; G. Pb, LAF33, CORD-MP 39213; H. Pa, LAF33, CORD-MP 39214; I. Polonodus newfoundlandensis (Stouge), Pb, LAF33, CORD-MP 39209; J. Dzikodus tablepointensis (Stouge), Pb, LAF33, CORD-MP 21723; K-L. Spinodus spinatus (Hadding); K. Sc, LAF27, CORD-MP 40650; L. P, LAF33, CORD-MP 40662; M-N. Polonodus galerus Albanesi; M. Pa, LAF27, CORD-MP 39194; N. Sc, LAF27, CORD-MP 39180; O. Scolopodus striatus Pander, Sc, SJF0, CORD-MP 40620; P-Q. Erraticodon alternans (Hadding); P. P, LAF27, CORD-MP 34449; Q. M, LAF27, CORD-MP 34395; R. Oistodella pulchra Bradshaw, P, SJF1, CORD-MP 35369; S-T. Rossodus barnesi Albanesi; S. M, SJF3, CORD-MP 40009; T. Sa, SJF3, CORD-MP 40140; U. Drepanoistodus costatus Abaimova, M, SJF7, CORD-MP 34007; V. Protopanderodus gradatus Serpagli, Sb-Sc, LAF27, CORD-MP 39400; W. Costiconus costatus (Dzik), Sb, SJF3, CORD-MP 33743; X. Parapanderodus paracornuformis Ethington and Clark, Pb, SJ, CORD-MP 35617; Y. Drepanodus arcuatus Pander, M, LAF33, CORD-MP 33760; Z Drepanodus reclinatus (Lindström), Pa, LAF33, CORD-MP 33890; AA. Cornuodus longibasis (Lindström), Sa, SJF3, CORD-MP 33692; AB. Protopanderodus robustus (Hadding), Sb-Sc, LAF27, CORD-MP 39750; AC. Juanognathus jaanussoni Serpagli, M, SJF6, CORD-MP 35209; AD. Venoistodus balticus (Löfgren), M, LAF2, CORD-MP 40665; AE. Semiacontiodus potrerillensis Albanesi, Sb, SJF6, CORD-MP 40441; AF. Paltodus jemtlandicus Löfgren, P, SJF3, CORD-MP 35380; AG. Parapaltodus simplicissimus Stouge, Sa, SJF3, CORD-MP 35615. 





E. pseudoplanus is more common in northern Estonia (Viira et al., 2001) where there are slightly shallower settings. In the Precordillera, D. tablepointensis was recovered on bedding planes from the lowest part of the middle member of the Los Azules Formation, along with other species that lived above euxinic bottom conditions (Ortega et al., 2007). The presence of E. pseudoplanus and D. tablepointensis may be used for the definition of an association zone for the Precordilleran region as they have similar ranges but different environmental requirements.

The index species Microzarkodina hagetiana and M. ozarkodella, which define the lower and upper subzones of the Eoplacognathus pseudoplanus Zone in the Baltoscandic region (Zhang, 1998b; Löfgren, 2004) have also been identified in the Precordillera. The upper boundary of this biozone is missing from the top of the lower member of the Las Aguaditas Formation because a stratigraphic gap separates the lower and middle members, indicated by the presence of Sandbian conodonts of the Pygodus anserinus Zone in the middle member. Although being the index of the lower subzone of the E. pseudoplanus Zone, $M$. hagetiana appears in the L. variabilis Zone (Löfgren and Tolmacheva, 2008). Because in the Las Aguaditas Formation this species was first documented from sample SJF4, in the Yangtzeplacognathus crassus Zone, it is necessary to find this species associated with D. tablepointensis or E. pseudoplanus in order to identify the $M$. hagetiana Subzone, as it was documented in sample LAF22. The top part of the lower member is a highly productive $1.1 \mathrm{~m}$ thick coquina. The E. pseudoplanus Zone is $24 \mathrm{~m}$ thick in the study section. In spite of the hiatus, it is thought that virtually the whole E. pseudoplanus Zone is represented in this section, based on the associated fauna and the fact that other index species typical of the topmost part of this zone were identified in the uppermost sample (LAF33). The index species Histiodella kristinae defines the lower subzone of the E. suecicus Zone in the Precordillera (Albanesi, 1998). However, in Scandinavia H. kristinae appears earlier in the record, in an interval where E. suecicus is not yet present (Zhang, 1998b; Löfgren, 2004). Also, this species was recovered along with its ancestor $H$. holodentata, which indicates early forms of $H$. kristinae as the evolving species. In addition, elements of Polonodus magnus Albanesi 1998 (synonym of Pygodus lunnensis Zhang, 1998c) were recovered, which in the Baltic scheme defines the lower subzone of the E. suecicus Zone. This may indicate that the level represents the E. suecicus Zone but the eponymous species was not recorded. This sample yields elements of E. pseudoplanus and previously unrecognised elements of Eoplacognathus. The Pa elements of the latter species exhibit an expansion of the platform of the posterior process, but they do not have a secondary denticle row in the posterior-lateral process, which Zhang (1998b, 1999) defines as a diagnostic character of E. suecicus. The Pa elements may belong to a new species of Eoplacognathus or considering the presence of some characters shared by E. pseudoplanus and its descendant E. suecicus (Zhang, 1999, Löfgren and Zhang, 2003), they may be intermediate forms, which could suggest a mosaic evolution of this genus.

This zone is represented by a conodont association including A. jemtlandica, A. sinuosa, B. clavatus, Bryantodina aff. typicalis, Coelocerodontus bicostatus, C. trigonius, Drepanodus arcuatus, Drepanodus robustus, Drepanodus aff. giganteus, D. costatus, D. tablepointensis, Fahraeusodus n. sp., H. holodentata, P. horridus, P. macrodentatus, P. zgierzensis, P. gradatus, $P$. robustus and Spinodus spinatus among others (Table 1).

\subsubsection{Regional and global correlation}

The E. pseudoplanus Zone of the lower member of the Las Aguaditas Formation correlates with the Las Chacritas Formation (Albanesi and Astini, 2000; Serra et al., 2013, 2015), Sierra de La Invernada Formation (Albanesi et al., 2009; Ortega et al., 2010) and the Los Azules Formation (Ortega et al., 2007) in the Precordillera.

This zone correlates with strata in the Yangtze valley of south-central China (Ni and Li, 1987; Zhang, 1998a), New Zealand (Zhen et al., 2011b) as well as at diverse localities in Baltoscandia, such as some from Estonia (Viira, 1974; Viira et al., 2001; Löfgren, 2004; Viira, 2011; Männik and Viira, 2012), Norway (Rasmussen, 2001), and Poland (Dzik, 1994). Since stratigraphically late forms of E. pseudoplanus were recovered, they enable a precise correlation with the Kunda-Aseri stage boundary interval in Sweden (Löfgren and Zhang, 2003; Mellgren and Eriksson, 2009).

\subsection{Pygodus anserinus Zone}

The paleontological record from the basal part of the middle member of the Las Aguaditas 
Formation is very restricted, in marked contrast with the highly productive upper part of the lower member. A clear difference in lithology indicates the boundary between the lower member with a calcareous coquina as the uppermost bed, and the middle member characterized by 5 to $20 \mathrm{~cm}$ thick beds of gray mudstone. The index species Pygodus anserinus was identified $4.5 \mathrm{~m}$ from the base, in sample LAgF1.5. The presence of the upper subzone of the $P$. anserinus Zone was confirmed by the identification of $B$. variabilis in $\mathrm{LAgF} 2$ which, according to Bergström (1971), indicates this interval. Moreover, a typical Sandbian graptolite association which consists of Leptograptus, Pseudoclimacograptus, Archiclimacograptus, Dicranograptus, Acrograptus and Dicellograptus, was recovered $10 \mathrm{~m}$ above the base of the middle member of the Las Aguaditas Formation (Albanesi et al., 2013). Nemagraptus gracilis indicating the Sandbian Stage was identified $c a .100 \mathrm{~m}$ above the base of the middle member (Serra et al., 2013).

A stratigraphic gap between the lower and middle members was recognized by the recovery of the index species $P$. anserinus in the lower part of the middle member. The hiatus spans the EOplacognathus suecicus and Pygodus serra zones and the lower subzone of the $P$. anserinus Zone. It is worth noting that this hiatus is recorded in the Siberian platform, in the Baltoscandic region and in China as well (Dronov et al., 2009; Schmitz et al., 2010).

\subsubsection{Regional and global correlation}

In the Precordillera, this zone has been identified in the Ponón Trehué Formation, in the Mendoza province (Heredia and Rosales, 2006), the Las Aguadita Formation in the Las Chacritas River section (Serra et al., 2013, 2015), in the La Invernada Formation (Ortega et al., 2008), and in Los Azules Formation at the La Chilca Hill (Albanesi, in Peralta et al., 2003).

This zone correlates with equivalent strata in Newfoundland (Bergström et al., 1974), the Marathon basin, Texas (Bergström, 1978), strata in the Great Basin and Rocky Mountains (Harris et al., 1979), Poland (Dzik, 1994), Sweden (Bergström, 1971, 2007), northwestern China (Zhen et al., 2011a), Thailand (Agematsu et al., 2007), Kazakhstan (Tolmacheva et al., 2009), and New South Wales in Australia (Zhen et al., 2003).

\subsection{Peridon macrodentatus Zone}

Periodon Hadding, 1913, is a widely distributed lineage, with a long stratigraphic range from the early Floian to the Late Ordovician (Löfgren and Tolmacheva, 2008). The zonal index species $P$. macrodentatus is the most abundant species in the study section. The lowest record occurs in the San Juan Formation (Sample SJF9), $21 \mathrm{~m}$ below the contact with the Las Aguaditas Formation. P. macrodentatus is present throughout the study interval in 28 of 45 samples. P. macrodentatus is also the most abundant species in the correlative interval at Newfoundland (Stouge, 2012). The upper boundary of this zone is defined by the FAD of Periodon zgierzensis in sample LAF27. The P. macrodentatus Zone is $48.5 \mathrm{~m}$ thick in the study section.

The three subzones of the $P$. macrodentatus Zone as defined by Stouge (2012) for Newfoundland were identified in the study section. The index species Histiodella sinuosa, which defines the lower subzone, was documented in sample SJF6 and $4 \mathrm{~m}$ above, in sample SJF4, where it is associated with Histiodella serrata, an intermediate form that connects $H$. sinuosa with $H$. holodentata. The latter species appears in sample SJF3 and defines the middle subzone up to the upper part of the lower member of the Las Aguaditas Formation, where elements of $H$. holodentata that belong to late forms of the species were recorded. These late forms are referred to by Stouge (2012) as Histiodella cf. holodentata, marking an evolutionary transition between $H$. holodentata and H. kristinae.

Several elements of the Oistodella pulchra apparatus have been identified from the San Juan Formation in the study section. Together with those documented for the Las Chacritas River section (Serra et al., 2015), these represent the few records of this species outside Laurentia. In North America, the species has been recovered from strata in the Cow Head Group in Newfoundland (Johnston and Barnes 2000; Stouge, 2012), and the Fort Peña Formation in the Marathon basin, Texas (Bradshaw, 1969).

The sequence of index species recorded in this study also matches the stratigraphic scheme proposed for the Tarim region, western China, by Chen et al. (2006), where the Periodon macrodentatus Zone is subdivided, in ascending order, into the H. holodentata, Y. crassus and Histiodella sp. A subzones. According to our records, we agree with 
Stouge (2012) in considering that the Histiodella cf. holodentata Subzone may be equivalent to the "Histiodella holodentata" Subzone of Chen et al. (2006).

\subsubsection{Regional and global correlation}

In the Precordillera, the recognition of the Periodon macrodentatus Zone allows the identification of coeval strata in the section of Cerro Potrerillo (Albanesi, 1998), Oculta Creek (Voldman et al., 2013), Las Chacritas River (Serra et al., 2013), Sierra de la Invernada (Albanesi et al., 2009), Ancaucha Creek (Voldman et al., 2008), Cerro la Chilca (Mestre and Heredia, 2012; Carrera et al., 2013), and Cerro Viejo de Huaco (Ortega et al., 2007), among others.

The Periodon and Histiodella lineages have great potential for global correlation (Stouge, 1984, 2012; Stouge et al., 2011; Chen et al., 2006; Stouge and Zhao, 2006) and support a correlation with equivalent strata in Canada (Uyeno and Barnes, 1970; Barnes and Poplawski, 1973; Pyle et al., 2003; Stouge, 2012), USA (Bauer, 2010; Graves and Ellison, 1941; Bradshaw, 1969), Norway (Rasmussen and Stouge, 1995; Rasmussen, 2001), Sweden (Stouge and Bagnoli, 1999; Löfgren, 2004; Mellgren and Eriksson, 2009), Estonia (Löfgren, 2004), China (e.g., Zhang, 1998a; Chen et al., 2006; Zhang and Gao, 1991; Zhao et al., 2000; Stouge and Zhao, 2006; Stouge et al., 2011; Zhen et al., 2011a), Australia (Zhen and Percival, 2004), New Zealand (Zhen et al., 2009; Zhen et al., 2011b), and Kazakhstan (Zhylkaidarov, 1998; Tolmacheva et al., 2004).

\subsection{Periodon zgierzensis Zone}

The lower boundary of this biozone is determined by the FAD of $P$. zgierzensis in sample LAF 27 , and it extends to the top of the lower member of the Las Aguaditas Formation. The contact with the middle member represents a hiatus, with Sandbian conodonts present in the basal strata of the latter unit. The index species appears together with its ancestor, $P$. macrodentatus, which also ranges up to the top of the lower member. However, in this time span we detect an increase in the representation of the younger species over its ancestor to the top of the column. H. kristinae was identified in the highest sample, LAF33, which indicates its lower subzone following Stouge (2012). It thickness is $15.5 \mathrm{~m}$ in the study section.

\subsubsection{Regional and global correlation}

This interval was constrained in the Las Aguaditas (Feltes et al., 2013) and Las Chacritas formations (Serra et al., 2015), but may be present at many localities. Some collections from the Precordillera should be revised because several elements that may belong to $P$. zgierzensis have been described as $P$. aculeatus zgierzensis or $P$. aculeatus sensu lato (e.g., Albanesi, 1998; Ortega et al., 2008; Heredia et al., 2011; Heredia, 2012; Heredia and Mestre, 2013b; Ortega et al., 2007). The index species $H$. kristinae that was first identified in the Precordillera by Sarmiento (1991) in the Gualcamayo Formation, at Sierra of Villicum, allows for precise correlation between several localities (for detail see the E. pseudoplanus Zone).

This biozone correlates with similar biostratigraphic intervals in western Newfoundland (Stouge, 1984, 2001, 2012; Stouge and Zhao, 2006), USA (Landing, 1976), China (Chen et al., 2006; Stouge et al., 2011), Scandinavia (Rasmussen, 2001) and New Zealand (Zhen et al., 2011b).

\section{Conodont abundance}

We examined patterns of conodont fauna replacement vertically within a single transgressive-regressive cycle. The conodont richness and abundance variation through the studied section shows strong evidence for shallowing and deepening patterns, in concordance with the lithology. This is shown in figure. 5 , where genera are ordered in terms of R-mode cluster, the diameter of the dot reflecting conodont taxa abundance.

The upper part of the San Juan Formation exhibits the greatest diversity of conodont genera, which are mostly well preserved. The lithology consists of nodular limestones and grainstones, which were deposited on a distal platform below the wave base and contain abundant fossils. Trilobites, brachiopods, orthocerid nautiloids and sponge spicules are also present in this unit. This facies indicates shallow environments suitable for the development of a wide variety of taxa with diverse lifestyles.

The first $18 \mathrm{~m}$ of the lower member of the Las Aguaditas Formation consists of dark grey mudstones interbedded with graptolitic black shales, which are characteristic of deep water environments. This is also supported by a marked decrease in the conodont fauna. The samples from this interval were almost barren; only a few, poorly preserved elements of 


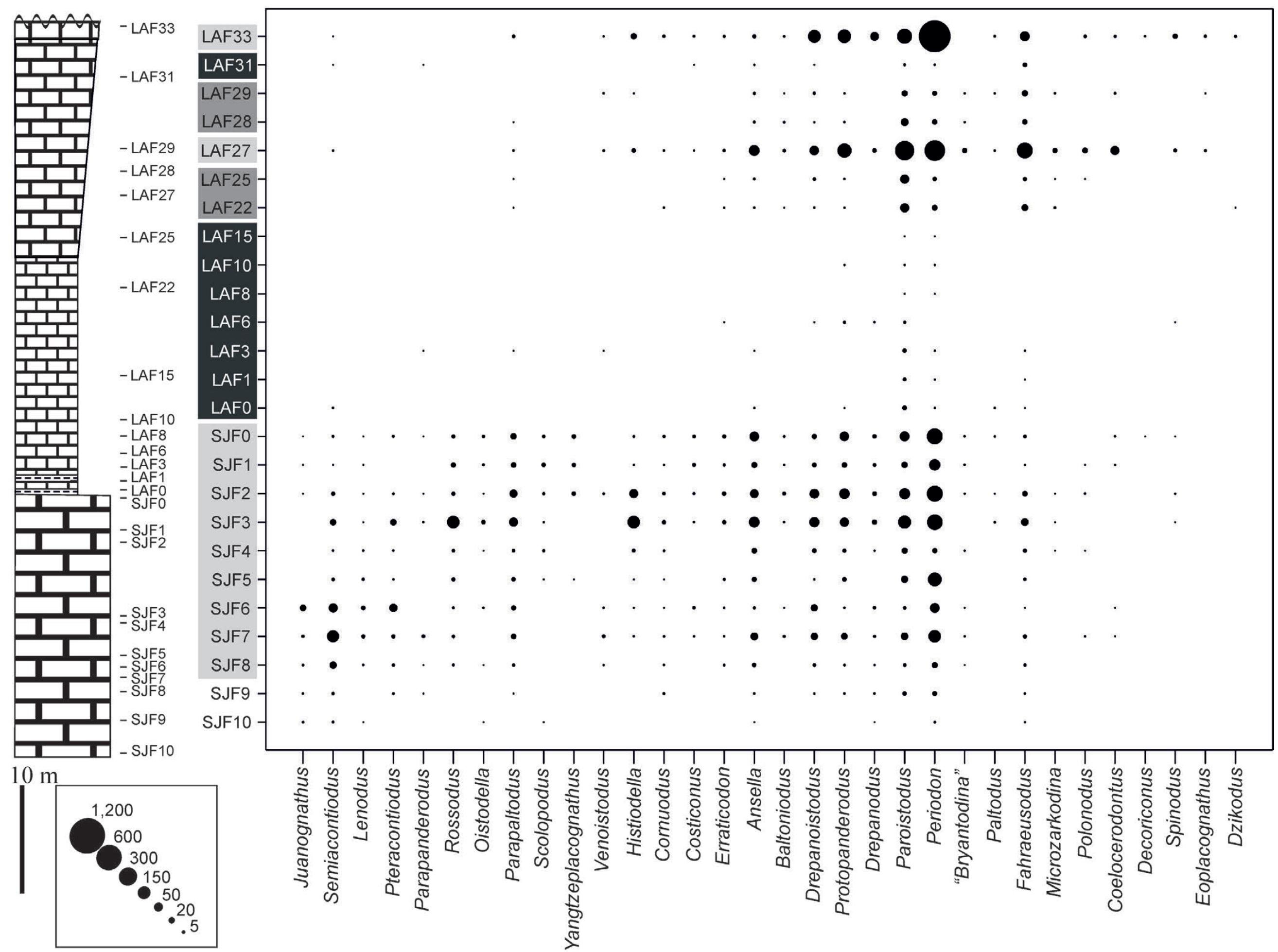

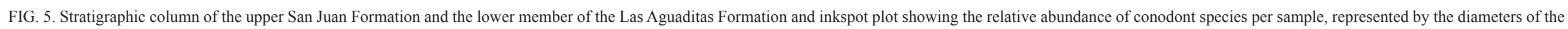
dots (R 3.1.2). 
diminished size were recovered. Only genera typical of a deep water environment, such as Periodon and Fahraeusodus, and pelagic taxa of Drepanodus, Paroistodus and Protopanderodus, were documented (Fortey and Barnes, 1977; Stouge, 1984; Bagnoli and Stouge, 1991; Albanesi, 1998). Pelagic trilobite larvae and ostracods were also recovered.

In the middle part of the lower member of the Las Aguaditas Formation there is a recovery in the conodont fauna. We also observed a change in the lithology from mudstone to wackestone-packstone, without significant packages of interbedded shales. This indicates a change in the depositional environment, which is supported by the fossil record.

A fluctuation in the conodont diversity in the upper half of the unit can be observed in Fig. 5. The conodont fauna diversity increases, reaching a peak in sample LAF27, and declining afterwards to zero values in some samples (these samples LAF30, LAF30.5 and LAF32 were eliminated from the analysis and thus cannot be seen in figure 5). A final diversity peak is reached in the top stratum of the unit (LAF33), which indicates a favorable environment for conodonts, this being also shown by the presence of robust elements.

The sudden recovery of the conodont fauna diversity is interpreted as reflecting a migration event into the basin, as most temporarily absent taxa reappear after the period of restrictive paleoenvironmental conditions. It is well established that conodonts were strongly environmentally controlled (e.g., Barnes and Fåhraeus, 1975; Fortey and Barnes, 1977; Sweet and Bergström, 1984; Rasmussen and Stouge, 1995; Zhang and Barnes, 2004). It is suggested that water temperature was probably the principal factor that governed their distribution (Sweet and Bergström, 1974).

A hierarchical cluster analysis was performed in order to determine the relationship of the samples (Fig. 6). Three associations were identified according to the taxonomic composition: a) Diverse conodont association, b) Low diversity conodont association and c) Recovery phase association.

a. Diverse conodont association: this association presents the highest richness values (samples yield 16 to 27 genera) and includes all the most productive samples from the study section (a total of 9,196 elements). The dominant genera are Periodon (3142 elements) and Paroistodus (1,264 elements), followed by Protopanderodus (800), Drepanoistodus (622), Ansella (579), Fahraeusodus (506) and Histiodella (313). This clustering reflects a similarity in the faunal composition and abundance of taxa between the top part of the San Juan Formation and the upper part of the Las Aguaditas Formation, suggesting recurrent environmental conditions. Most temporarily absent taxa reappear indicating local migration events. New genera are also recorded in samples LAF27 and LAF33, as a result of the time span between the latter samples (E. pseudoplanus Zone) and those from the San Juan Formation (L. variabilis$Y$. crassus zones), where speciation or complex diversification events could have taken place.

b. Low diversity conodont association: this association includes the samples from the lower part of the lower member of the Las Aguaditas Formation, which are almost barren, and sample LAF31 from the upper part, reflecting the diversity fluctuation that began in LAF22, as described above. The conodont abundance and diversity and richness is very low compared to the other associations. In most samples only the genus Paroistodus is present, though sometimes it is accompanied by Periodon, Fahraeusodus and pelagic forms, such as Drepanodus, Protopanderodus and Drepanoistodus.

c. Recovery phase association: four samples from the middle part of the lower member of the Las Aguaditas Formation were clustered. These represent the beginning of a shallowing event which is supported by a change in the lithology and the reappearance of Cornuodus (Löfgren, 1999a). The intermediate environmental setting, in relation to the previous associations, allowed the conodont fauna to emigrate to the basin which is reflected in the recovery of conodont genera and their abundance. The most abundant taxa are Paroistodus (260 elements), Fahraeusodus (111 elements) and Periodon (85 elements), which are characteristic of deep water conditions as in the previous association, although the appearance of new genera indicates different, more favorable, environmental conditions.

\section{Discussion}

Albanesi (1998) defined the P. gladysae Subzone as the lower unit of the L. variabilis Zone in the Cerro Potrerillo and Portezuelo de Yanso sections in the Central Precordillera. Mestre and Heredia (2009) attempted to remove the $P$. gladysae Subzone based on an incorrect interpretation of the index species $P$. 


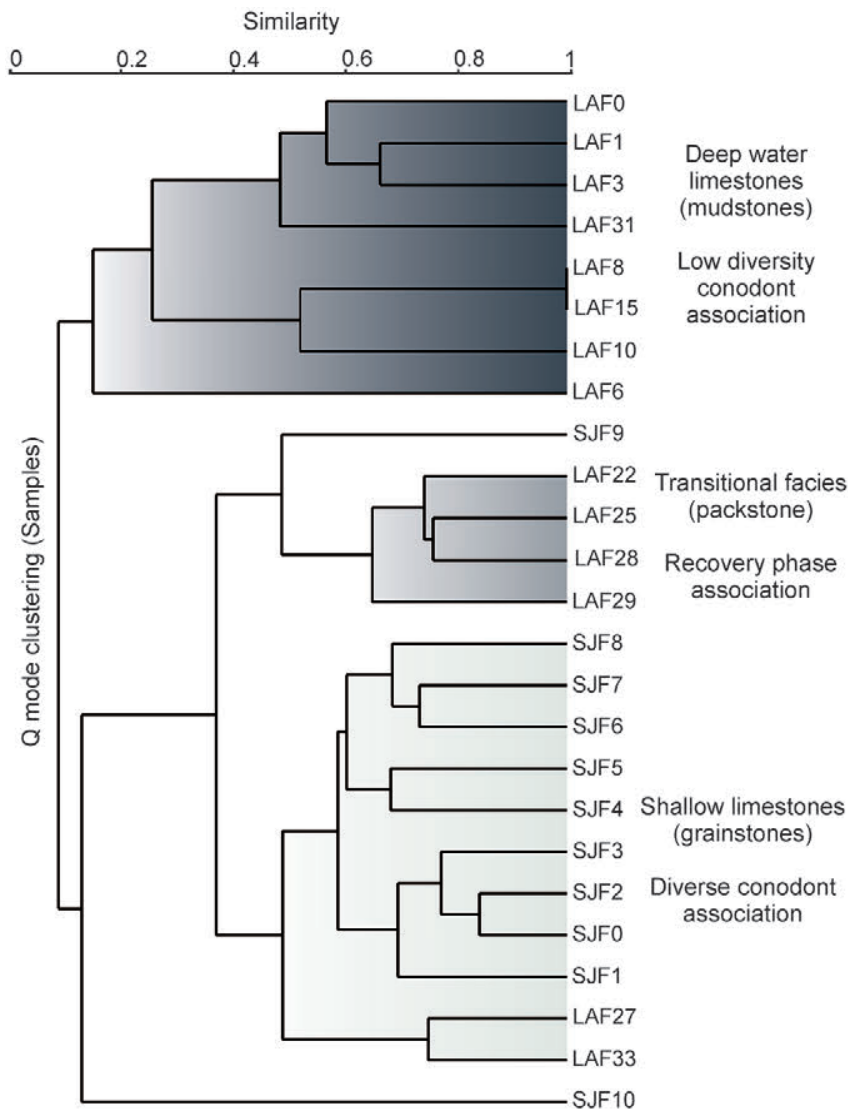

FIG. 6. Q-mode cluster analysis of samples from the upper San Juan Formation and the lower member of the Las Aguaditas Formation showing the three conodont associations (PAST 2.15).

gladysae and L. variabilis as determined by Albanesi (1998), reassigning those elements to M. ozarkodella and E. pseudoplanus, respectively. The present study agrees with Albanesi (1998) because in the equivalent levels the diagnostic $\mathrm{M}$ and $\mathrm{Pa}$ elements of $L$. variabilis are identified in association with P. gladysae. In addition, M. ozarkodella is identified in the upper part of the formation and is derived from $M$. hagetiana, which is consistent with the phylogeny of the genus described by Löfgren and Tolmacheva (2008) and associated conodont index species.

The report of the occurrence of $P$. serra by Eberlein (1990), Keller et al. (1993) and Lehnert (1995), was not confirmed. The stratigraphic gap between the lower and the middle members of the Las Aguaditas Formation embraces the E. suecicus, $P$. serra and the lower subzone of the $P$. anserinus zones. It is unlikely that $P$. serra could be present in the middle member since according to Zhang (1997) its range barely overlaps with $P$. anserinus. The hiatus in between the members is interpreted as representing the Ocloyic tectonic phase (Astini, 1994).

Periodon represents $33 \%$ of the conodont elements in the collection. It is present in 29 of the total 46 samples that encompass a wide variety of environments. Although the species that represent the Histiodella lineage are not as abundant as those of Periodon, they show a continuous record through the study interval. This is not the case for the zonal index species of the Baltic scheme, L. variabilis, Y. crassus and E. pseudoplanus, which are not abundant in the study section, and the same is the case at other localities on the Precordilleran basin. In addition, platform-bearing taxa are less useful as zonal index species as they are restricted to specific facies (Rasmussen, 2001). Moreover, in south-central China E. pseudoplanus was not sufficiently abundant to be useful as an index fossil (Zhang, 1998a). The Periodon and Histiodella 
assemblages have a demonstrated usefulness for correlation across the Iapetus Ocean (Rasmussen and Stouge, 1995; Rasmussen, 2001).

The record of Oistodella pulchra in only the Precordillera and Laurentia indicates a faunal exchange between these two regions. This species was recovered from samples of the upper San Juan Formation at the study section and at the Las Chacritas River section (Serra et al., 2015), in platform facies. In the Cow Head Group, Newfoundland, Stouge (2012) recovered $O$. pulchra from 7 samples of wackstone-packstone. In the original paper that defines the species, Bradshaw (1969) did not specify the provenance of each sample. However, it was explained that conodonts were recovered from limestones, conglomeratic limestones and conglomerate beds, and samples that consist of shales and chert did not yield conodonts.

The presence of Cornuodus longibasis and the high abundance of Semiacontiodus potrerillensis in the upper part of the San Juan Formation, their subsequent disappearance in the lower part of the lower member of the Las Aguaditas Formation and the reappearance of both species in the middle and upper parts, suggest their preferences for shallower settings in the basin. According to Löfgren (1999a, 1999b, 2003, 2004) Semiacontiodus and Cornuodus are associated with shallowest settings in central Baltoscandia. In contrast, in the same intervals Costiconus costatus, and the highest abundance of Periodon were documented, which are reliable indicators of relatively deep water (Barnes and Fåhraeus, 1975; Lindström, 1976; Pohler, 1994). These intervals were the most productive intervals in the study section $(99.9 \%$ of the total number of elements in the collection were recovered from samples of those intervals). The lower part of the lower member (from LAF0 to LAF21) was nearly barren except for a few taxa, such as Periodon macrodentatus, Paroistodus horridus and Protopanderodus gradatus that were recorded in low numbers, apparently representing the referred interval a conditioning environment for most taxa.

\section{Conclusions}

The index conodont species and associated fauna recorded from the San Juan Formation, and the lower member and basal strata of the middle member of the Las Aguaditas Formation at its type section, allow the establishment of a high resolution biostratigraphic scheme for the middle Darriwilian to Sandbian in the
Precordillera, which is useful for global correlation. The following biozones are identified in the study section (Fig. 7): the Lenodus variabilis Zone, with the Periodon gladysae and Paroistodus horridus Subzones according to the Precordilleran scheme (Albanesi and Ortega, 2002); the Lenodus variabilis, Yangtzeplacognathus crassus, and the Eoplacognathus zones with the Microzarkodina hagetiana and $M$. ozarkodella subzones, as well as the Pygodus anserinus Zone, representing the Scandinavian scheme (Löfgren and Zhang, 2003); the Periodon macrodentatus Zone, with the Histiodella sinuosa, Histiodella holodentata and $H$. cf. holodentata subzones, and the P. zgierzensis Zone with the $H$. kristinae Subzone proposed recently for North America (Stouge, 2012). A stratigraphic gap that encompasses the E. suecicus, P. serra and the lower subzone of the $P$. anserinus zones was recognized between the lower and middle members of the Las Aguaditas Formation.

The variation in conodont diversity and the recovery of some particular taxa through the studied section show strong evidence for shallowing and deepening patterns which is in accordance with the lithology. Three associations were quantitatively identified according to the taxonomic composition of the samples: a) Diverse conodont association, b) Low diversity conodont association and c) Recovery phase association. Also a local migration event is suggested to explain the conodont association recurrence between the upper part of the San Juan Formation and the upper part of the lower member of the Las Aguaditas Formation.

Based on the notable difference in the abundance of the zonal index taxa in stratigraphic units on diverse localities in the Central Precordillera, we propose to use the North American biozonal scheme for the Precordillera. This also allows further correlation with Australia, New Zealand and Kazakhstan, where the index species of the Baltic scheme are either scarce or absent. Also the resolution of correlation by the application of phylozones is more reliable than other biostratigraphic methods.

The current conodont biostratigraphy for the Las Aguaditas Formation establishes a lower member $43 \mathrm{~m}$ thick of middle Darriwilian age, and a middle and upper member of Sandbian age. Further work is in progress with the goal of establishing a detailed conodont biostratigraphic scheme for the middle member and the upper members of the Las Aguaditas Formation. 


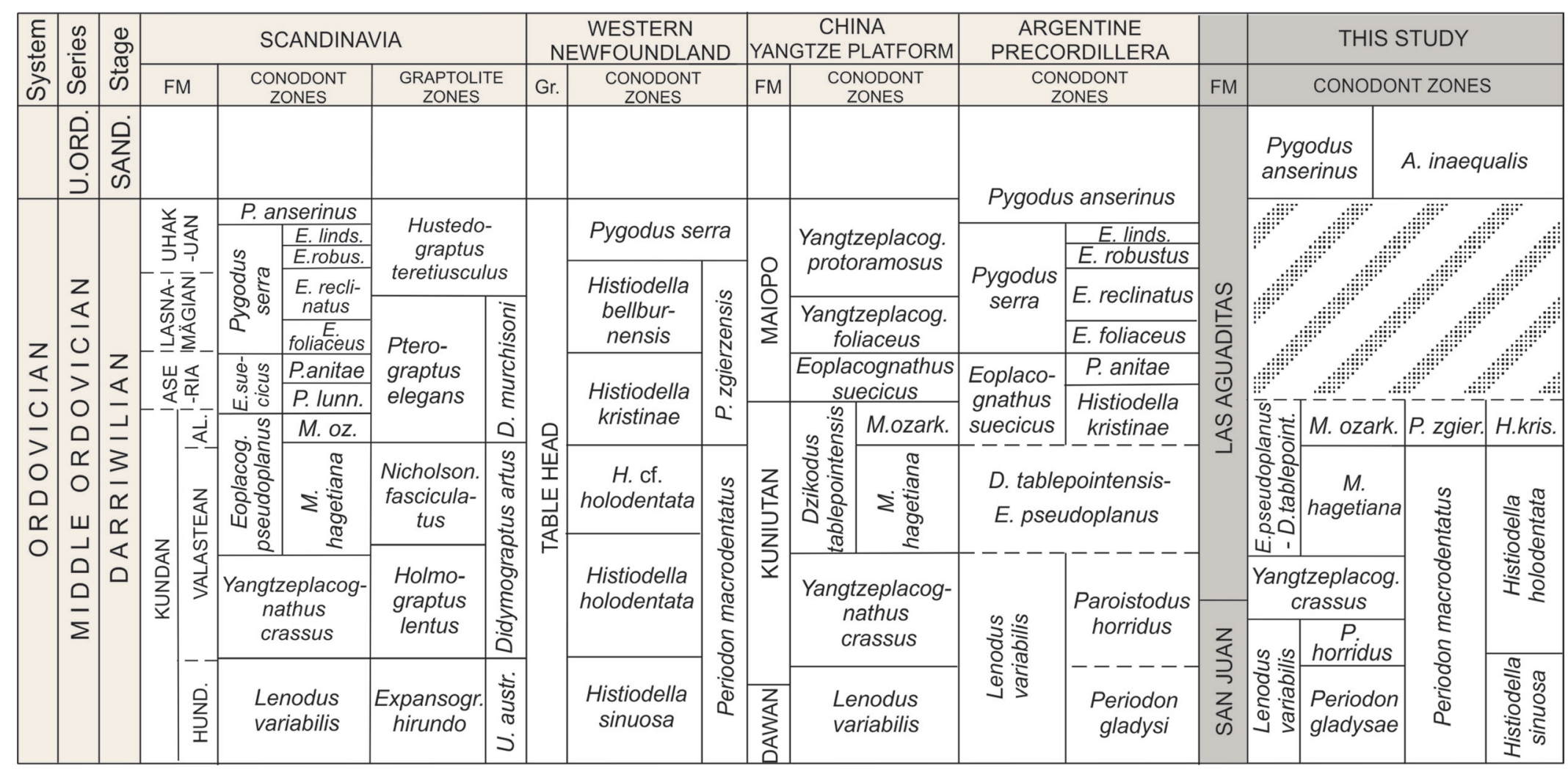

FIG. 7. Biostratigraphic chart of the Middle-Upper Ordovician showing conodonts and graptolites zones from Scandinavia, Western Newfoundland, China Yangtze platform, the Argentine Precordillera and the study section. Abbreviations: U. ORD: Upper Ordovician; SAND: Sandbian; Gr: Group; M. ozark. - M. ozarkodella; P. zgier. - P. zgierzensis; H. kris. - H. kristinae; D. tablepoint - D. tablepointensis; Yangtzeplacog - Yangtzeplacognathus. 


\section{Acknowledgement}

This study is part of the Ph.D. thesis of the senior author in the Universidad Nacional de Córdoba (UNC). We acknowledge the Consejo Nacional de Investigaciones Científicas y Técnicas (CONICET, Argentina) and Secretaría de Ciencia y Tecnología (SECYT-UNC) for granting the present work. We also thank the Centro de Investigaciones en Ciencias de la Tierra CICTERRA(CONICET-UNC) and Centro de Investigaciones Geológicas Aplicadas CIGEA (FCEFyN-UNC) where this research was carried out. The authors appreciate the valuable help given by Dra. G. Ortega and biologist F. Serra during the development of this paper. Our particular thanks to the reviewer Dr. I. Percival, who made useful suggestions in order to improve the final presentation of this paper.

\section{References}

Aceñolaza, F.G.; Miller, H.; Toselli, A.J. 2002. ProterozoicEarly Paleozoic evolution in western South America-A discussion. Tectonophysics 354: 121-137.

Agematsu, S.; Sashida, K.; Salyapongse, S.; Sardsud, A. 2007. Ordovician conodonts from the Satun area, Southern Peninsular Thailand. Journal of Paleontology 8: 19-37.

Albanesi, G.L. 1998. Taxonomía de conodontes de las secuencias ordovícicas del cerro Potrerillo, Precordillera Central de San Juan, R. Argentina. In Actas de la Academia Nacional de Ciencias, No. 12: 102-253. Córdoba.

Albanesi, G.L.; Ortega, G. 1998. Conodont and Graptolite Faunas from the Las Plantas Formation and equivalent units (Caradoc) in the Argentine Precordillera. In International Conodont Symposium held in Europe, No7: Abstracts: 1-2. Bologna-Modena.

Albanesi, G.L.; Astini, R.A. 2000. Bioestratigrafía de conodontes de la Formación Las Chacritas, Precordillera de San Juan, Argentina. Reunión de Comunicaciones de la Asociación Paleontológica Argentina, Mar del Plata. Ameghiniana 37 (4): 68-69R.

Albanesi, G.L.; Barnes, C.R. 2000. Subspeciation within a punctuated equilibrium evolutionary event: phylogenetic history of the lower-middle Ordovician Paroistodus originalis- $P$. horridus complex (Conodonta). Journal of Paleontology 74 (3): 492-502.

Albanesi, G.L.; Ortega, G. 2002. Advances on conodontgraptolite biostratigraphy of the Ordovician System of Argentina. In Aspects of the Ordovician System in Argentina (Aceñolaza, F.G.; editor). Instituto Superior de Correlación Geológica, Serie Correlación Geológica, No. 16: 143-165. San Miguel de Tucumán.
Albanesi, G.L.; Bergström, S.M. 2010. Early-Middle Ordovician conodont paleobiogeography with special regard to the geographic origin of the Argentine Precordillera: A multivariate data analysis. Geological Society of America, Special Paper 466: 119-139.

Albanesi, G.L.; Benedetto, J.L.; Gagnier, P.Y. 1995a. Sacabambaspis janvieri (Vertebrata) y conodontes del Llandeiliano temprano en la Formación La Cantera, Precordillera de San Juan, Argentina. Boletín Academia Nacional de Ciencias 60 (3-4): 519-544. Córdoba.

Albanesi, G.L.; Ortega, G.; Hünicken, M.A. 1995b. Conodontes y graptolitos de la Formación Yerba Loca (Arenigiano-Llandeiliano) en las quebradas de Ancaucha y El Divisadero, Precordillera de San Juan, Argentina. Boletín Academia Nacional de Ciencias 60 (3-4): 365-400. Córdoba.

Albanesi, G.L.; Hünicken, M.A.; Barnes, C.R. 1998. Bioestratigrafía, Biofacies y Taxonomía de conodontes de las secuencias ordovícicas del cerro Potrerillo, Precordillera Central de San Juan, República Argentina. Boletín de la Academia Nacional de Ciencias 12: 253 p. Córdoba.

Albanesi, G.L.; Bejerman, A.M.; Astini, R.A. 2009. Conodont biostratigraphy and paleoenvironments of the lower Sierra de La Invernada Formation, Middle Ordovician, San Juan Precordillera, Argentina. International Conodont Symposium, Abstracts, Permophiles 53: 1-2.

Albanesi, G.L.; Carrera, M.G.; Cañas, F.L.; Saltzman, M. 2006. A proposed global boundary stratotype section and point (GSSP) for the base of the Middle Ordovician Series: The Niquivil section, Precordillera of San Juan, Argentina. Episodes 29: 1-15.

Albanesi, G.L.; Bergström, S.M.; Schmitz, B.; Serra, F.; Feltes, N.A.; Voldman, G.G.; Ortega, G. 2013. Darriwilian (Middle Ordovician) $\delta^{13} \mathrm{C}_{\text {carb }}$ chemostratigraphy in the Precordillera of Argentina: Documentation of the middle Darriwilian Isotope Carbon Excursion (MDICE) and its use for intercontinental correlation. Palaeogeography, Palaeoclimatology, Palaeoecology 389: 48-63.

Astini, R.A. 1994. Geología e interpretación de la Formación Gualcamayo en su localidad clásica (suroeste de Guandacol y cordón de Perico-Potrerillo), Precordillera septentrional. Revista de la Asociación Geológica Argentina 49 (1-2): 55-70.

Astini, R.A. 1995. Sedimentología de la Formación Las Aguaditas (talud carbonático) e implicancias estratigráficas en la cuenca precordillerana durante el Ordovícico medio. Revista de la Asociación geológica Argentina 50: 143-164. 
Astini, R.A. 1997. Las unidades calcáreas del Ordovícico Medio y Superior de la Precordillera Argentina como indicadores de una etapa extensional. In Jornadas de Geología de Precordillera, No. 2, Actas: 8-14. San Juan.

Astini, R.A.; Benedetto, J.L.; Vaccari, N.E. 1995. The Early Paleozoic evolution of the Argentine Precordillera as a Laurentinan rifted, drifted and collided terrane: A Geodynamic model. Geological Society of American Bulletin 107: 253-273.

Bagnoli, G.; Stouge, S. 1991. Paleogeographic distribution of Argentinian (Lower Ordovician) conodonts. Anais da Academia Brasileira de Ciências 63: 171-183.

Baldis, B.A.; Blasco, G. 1974. Trilobites ordovícicos de la comarca de Jáchal, Precordillera Argentina. I. Telephinidae. Ameghiniana 11: 71-87.

Baldis, B.; Beresi, M.; Bordonaro, O.; Vaca, A. 1982. Síntesis evolutiva de la Precordillera Argentina. In Congreso Latinoamericano de Geología, No. 5: 399-445. Buenos Aires.

Barnes, C.R.; Poplawski, M.L.S. 1973. Lower and Middle Ordovician conodonts from the Mystic Formation, Quebec, Canada. Journal of Paleontology 47: 760-790.

Barnes, C.; Fåhræus, L. 1975. Provinces, communities and the proposed nektobenthic habit of Ordovician conodontophorids. Lethaia 8 (2): 133-149.

Bauer, J.A. 2010. Conodonts and Conodont Biostratigraphy of the Joins and Oil Creek Formations, Arbuckle Mountains, South-central Oklahoma. Oklahoma Geological Survey Bulletin 150: 1-44.

Benedetto, J.L. 1993. La hipótesis de la aloctonía de la Precordillera argentina: un test estratigráfico y biogeográfico. Congreso Geológico Argentino, No. 12, Actas 3: 375-384. Mendoza.

Benedetto, J.L. 2004. The allochthony of the Precordillera ten years later (1993-2003): A new paleobiogeographic test of the microcontinental model. Gondwana Research 7: 1027-1039.

Benedetto, J.L. 2010. El continente de Gondwana a través del tiempo. Una introducción a la Geología Histórica. Academia Nacional de Ciencias, Academia Nacional de Ciencias: 373 p. Córdoba.

Benedetto, J.L.; Vaccari, N.E.; Waisfeld, B.G.; Sánchez, T.M.; Foglia, R.D. 2009. Cambrian and Ordovician biogeography of the South American margin of Gondwana and accreted terranes. In Early Palaeozoic Peri-Gondwanan terranes: New Insights from Tectonics and Biogeography (Bassett, M.G.; editor). Geological Society, Special Publications 325: 201-232. London.

Bergström, S.M. 1971. Conodont biostratigraphy of the Middle and Upper Ordovician of Europe and
Eastern North America. In Symposium on Conodont Biostratigraphy (Sweet, W.C.; Bergström, S.M.; editors), Geological Society of America Memoir, No. 127: 83-161. Boulder.

Bergström, S.M. 1978. Middle and Upper Ordovician conodont and graptolite biostratigraphy of the Marathon, Texas graptolite zone reference standard. Palaeontology 21 (4): 723-758

Bergström, S.M. 2007. The Ordovician conodont biostratigraphy of the Siljan region, south-central Sweden: A brief review of an international reference standard. Sveriges Geologiska Undersökning (Geological Survey of Sweden) Rapporter och Meddelanden 128: 26-41; 63-78.

Bergström, S.M.; Riva, J.; Kay, M. 1974. Significance of conodonts, graptolites, and shelly faunas from the Ordovician of Western and North-Central Newfoundland. Canadian Journal of Earth Sciences 11: 1625-1660.

Bordonaro, O.L.; Banchig, A.L. 1995. Trilobites laurénticos en el Cámbrico de la Precordillera Argentina. In Congreso Argentino de Paleontología y Bioestratigrafía, No. 6, Actas: 59-65. Trelew.

Bradshaw, L.E. 1969. Conodonts from the Fort Peña Formation (Middle Ordovician), Marathon Basin, Texas. Journal of Paleontology 43 (5): 1137-1168.

Cañas, F.L. 1999. Facies and sequences of the late Cambrian-early Ordovician carbonates of the Argentine Precordillera: a stratigraphic comparison with Laurentian platforms. Geological Society of America, Special Paper 336: 43-62.

Carrera, M.G. 1997. Evolución y recambio de las Faunas de Poríferos y Briozoos en el Ordovícico de la Precordillera Argentina. Ameghiniana 34: 295-308.

Carrera, M.G.; Astini, R.A. 1998. Valoración de las restricciones ambientales durante la transición Arenigiano-Llanvirniano, Ordovícico de la Precordillera. Revista Asociación Geológica Argentina 53: 41-56.

Carrera, M.G.; Ernst, A. 2010. Darriwilian bryozoans from the San Juan Formation (Ordovician), Argentine Precordillera. Ameghiniana 47 (3): 343-354.

Carrera, M.G.; Fenoglio, F.; Albanesi, G.L.; Voldman, G. 2013. Conodonts, sequence stratigraphy and the drowning of the San Juan carbonate platform in the Ordovician of the Argentine Precordillera. In Conodonts from the Andes (Albanesi, G.L.; Ortega, G.; editors). International Conodont Symposium, No. 3. Asociación Paleontológica Argentina, Special Publication 13: 5-12. Buenos Aires. 
Chen, M.Y.; Zhang, J.H. 1989. Ordovician conodonts from the Shitai region, Anhui. Acta Micropaleontologica Sinica 6: 213-228.

Chen, X.; Zhang, Y.D.; Bergström, S.M.; Xu, H.G. 2006. Upper Darriwilian graptolite and conodont zonation in the global stratotype section of the Darriwilian stage (Ordovician) at Hungnitang, Chengshan, Zhejiang, China. Palaeoworld 15 (2): 150-170.

Dronov, A.V.; Kanygin, A.V.; Timokhin, A.V.; Tolmacheva, T.Ju.; Gonta, T.V. 2009. Correlation of Eustatic and Biotic Events in the Ordovician Paleobasins of the Siberian and Russian Platforms. Paleontological Journal 43 (11): 1477-1497.

Dzik, J. 1994. Conodonts of the Mójcza Limestone. In Ordovician carbonate platform ecosystem of the Holy Cross Mountains (Dzik, J.; Olempska, E.; Pisera, A.; editors). Palaeontologia Polonica 53: 43-128.

Erlström, M.; Ahlberg, P.; Löfgren, A. 2001. Lower Palaeozoic stratigraphy at Luby and Tängelås, central Scania, southern Sweden. GFF 123: 7-14.

Eberlein, S. 1990. Conodontenstratigraphie und Facies der Formation Las Aguaditas (Ordovizium/Argentinische Präkordillere). Friedrich-Alexander Universität Erlangen-Nürnberg, Institut für Geologisches, Unveröfftl, Diplom Arbeit: p. 83. Erlangen.

Epstein, A.G.; Epstein, J.B.; Harris, L.D. 1977. Conodont color alteration-an index to organic metamorphism. United States Geological Survey, Professional Paper 995: 1-27.

Feltes, N.A.; Albanesi, G.L.; Bergström, S.M. 2013. Middle Darriwilian conodonts biozones from the Lower Member of the Las Aguaditas Formation, Central Precordillera of San Juan, Argentina. In Conodonts from the Andes (Albanesi, G.L.; Ortega, G.; editors). International Conodont Symposium, No. 3. Asociación Paleontológica Argentina, Special Publication 13: 25-31. Buenos Aires.

Feltes, N.A.; Serra, F.; Albanesi, G.L.; Voldman, G.G. 2014. La zona de Yangzteplacognathus crassus en el contacto entre las formaciones San Juan y las unidades suprayacentes en la Precordillera Central de San Juan, Argentina. In Congreso Geológico Argentino, No 19, Actas S2: 11. Córdoba.

Finney, S. 2007. The Parautochthonous Gondwana origin of the Cuyania (greater Precordillera) terrane of Argentina: a re-evaluation of evidence and use to support and allochthonous Laurentian origin. Geologica Acta 5: 127-158.

Fortey, R.A. 1984. Global earlier Ordovician transgressions and regressions and their biological implications.
In Aspects of the Ordovician System (Bruton, D.; editor). Palaeontological Contributions from the University of Oslo 295: 37-50. Oslo.

Fortey, R.A.; Barnes, C.R. 1977. Early Ordovician conodont and trilobite communities of Spitsbergen: influence on biogeography. Alcheringa 1: 297-309.

Furque, G.; Cuerda, A. 1979. Precordillera de La Rioja, San Juan y Mendoza. Segundo Simposio de Geología Regional Argentina, Córdoba. Boletín de la Academia Nacional de Ciencias I: 455-522. Córdoba.

Graves, R.W. Jr.; Ellison, S. 1941. Ordovician conodonts of the Marathon Basin, Texas. University of Missouri, School of Mines and Metallurgy, Bulletin 14: $1-26$

Hadding, A.R. 1913. Undre dicellograptusskiffern i Skåne Jämte några darmed ekvivalenta bildningar. Lunds Universitets Årsskrift N.F. 2, 9 (15): 1-90.

Hammer, Ø.; Harper, D.A.T.; Ryan, P.D. 2001. PAST: Paleontological statistics software package for education and data analysis. Palaeontología Electrónica 4 (1): 9 p.

Harris, A.G.; Bergström, S.M.; Ethington, R.L.; Ross, R.J.Jr. 1979. Aspects of Middle and Upper Ordovician conodont biostratigraphy of carbonate facies in Nevada and southeast California and comparison with some Appalachian successions. Brigham Young University, Geology Studies 26: 7-43.

Heredia, S.E. 2012. Bioestratigrafía de conodontes del Darriwiliano medio (Ordovícico) de Argentina: la Formación Las Aguaditas, Precordillera Central. Revista Mexicana de Ciencias Geológicas 29 (1): 76-86.

Heredia, S.; Rosales, C. 2006. Biofacies de Conodontes de la Formación Ponón Trehué y la importancia bioestratigráfica como sección tipo para el límite del Ordovícico Medio-Ordovícico Superior de Cuyania (Argentina). Serie Correlación Geológica 21: 7-16.

Heredia, S.; Mestre, A. 2013a. Advances in the middle Darriwilian conodont biostratigraphy of the Argentine Precordillera. In Conodonts from the Andes (Albanesi G.L.; Ortega, G.; editors). International Conodont Symposium, No. 3. Asociación Paleontológica Argentina, Special Publication 13: 45-47. Buenos Aires.

Heredia, S.; Mestre, A. 2013b. El conodontes darriwiliano Lenodus variabilis (Sergeeva) en la Precordillera Central de San Juan, Argentina. Serie Correlación Geológica 29 (1): 89-100.

Heredia, S.E.; Beresi, M.; Peralta, S. 2011. Estratigrafía y bioestratigrafía del Ordovícico Medio del río Las Chacritas, Precordillera Central de San Juan. Serie Correlación Geológica 27: 18-26. 
Huff, W.D.; Davis, D.; Bergström, S.M.; Krekeler, M.P.S.; Kolata, D.R.; Cingolani, C. 1997. A biostratigraphically well-constrained K-bentonite U-Pb zircon age of the lowermost Darriwilian Stage (Middle Ordovician) from the Argentine Precordillera. Episodes 20: 29-33.

Johnston, D.I.; Barnes, C.R. 2000. Early and Middle Ordovician (Arenig) conodonts from St. Pauls Inlet and Martin Point, Cow Head Group, western Newfoundland, Canada. 2 Systematic Paleontology. Geologica et Paleontologica 34: 11-87.

Juggins, S. 2015. Rioja: Analysis of Quaternary Science Data, R package version (0.9-5). http://cran.r-project. org/package=rioja (last visit 06-01-2016).

Keller, M.; Eberlein, S.; Lehnert, O. 1993. Sedimentology of Middle Ordovician carbonates in the Argentine Precordillera: evidence of regional relative sea-level changes. Geologische Rundschau 82: 362-377.

Landing, E. 1976. Early Ordovician (Arenigian) conodont and graptolite biostratigraphy of the Taconic allochthon, eastern New York. Journal of Paleontology 50: 614-646.

Lehnert, O. 1995. Ordovizische Conodonten aus der Präkordillere Westargentiniens: Ihre Bedeutung für Stratigraphie und Paläogeographie. Erlanger Geologische Abhandlungen 125: 1-193.

Lehnert, O.; Bergström, S.M.; Keller, M.; Bordonaro, O. 1999. Ordovician (Darriwilian-Caradocian) conodonts from the San Rafael Region, West-central Argentina: biostratigraphic, paleoecologic, and paleogeographic implications. Bollettino della Società Paleontologica Italiana 37 (2-3): 199-214.

Lindström, M. 1976. Conodont Paleogeography of the Ordovician. In The Ordovician System (Bassett, M.G.; editor). Palaeontological Association Symposium Proceedings, University of Wales Press and National Museum of Wales: 501-522. Cardiff.

Löfgren, A. 1978. Arenigian and Llanvirnian conodonts from Jämtland, northern Sweden. Fossils and Strata 13: $1-129$.

Löfgren, A.M. 1999a. A septimembrate apparatus model for the Ordovician conodont genus Cornuodus Fåhraeus, 1966. Bollettino della Societa Paleontologica Italiana 37 (2-3): 175-86.

Löfgren, A.M. 1999b. The Ordovician conodont Semiacontiodus cornuformis (Sergeeva, 1963) and related species in Baltoscandia. Geologica et Palaeontologica 33: 71-91.

Löfgren, A.M. 2000. Early to early Middle Ordovician conodont biostratigraphy of the Gillberga quarry, northern Öland, Sweden. GFF 122: 321-338.
Löfgren, A. 2003. Conodont faunas with Lenodus variabilis in the upper Arenigian to lower Llanvirnian of Sweden. Acta Palaeontologica Polonica 48 (3): 417-436.

Löfgren, A.M. 2004. The conodont fauna in the Middle Ordovician Eoplacognathus pseudoplanus Zone of Baltoscandia. Geological Magazine 141: 505-524.

Löfgren, A.; Zhang, J. 2003. Element association and morphology in some Middle Ordovician platformequipped conodonts. Journal of Paleontology 77 : 721-737.

Löfgren, A.; Tolmacheva, T. 2008. Morphology, evolution and stratigraphic distribution in the Middle Ordovician conodont genus Microzarkodina. Earth and Environmental Science Transactions of the Royal Society of Edinburgh 99: 27-48.

Männik, P.; Viira, V. 2012. Ordovician conodont diversity in the northern Baltic. Estonian Journal of Earth Sciences 61: 1-14.

Mellgren, J.I.S.; Eriksson, M.E. 2009. Untangling a Darriwilian (Middle Ordovician) palaeoecological event in Baltoscandia: conodont faunal changes across the "Täljsten" interval. Earth and Environmental Science Transactions of the Royal Society of Edinburgh 100: 353-370

Mestre, A. 2013. Middle Darriwilian conodont biostratigraphy of the Villicum Range, Eastern Precordillera, Argentina. Asociación Paleontológica Argentina, Publicación Especial 13: 69-72.

Mestre, A.; Heredia, S.E. 2009. La Subzona de Periodon gladysi (Conodonta) en el Ordovícico Medio de Precordillera: Su evaluación. Serie de Correlación Geológica 25: 123-128

Mestre, A.; Heredia, S.E. 2012. Darriwilian species of the genus Histiodella (Conodonta) in the Argentina Precordillera. Alcheringa 36: 141-150.

Ni, S.Z.; Li, Z.H. 1987. Conodonts. In Biostratigraphy of the Yangtze Gorge area 2: Early Palaeozoic Era (Wang, X.F.; Ni, S.Z.; Zeng, Q.L.; Xu, G.H.; Zhou, T.M.; Li, Z.H.; Xiang, L.W.; Lai, C.G.; editors). Geological Publishing House: 386-447, 549-555, 619-632. Beijing.

Ortega, G.; Albanesi, G.L.; Hünicken, M.A. 1995. Bioestratigrafía en base a conodontes y graptolitos de las Formaciones San Juan (techo) y Gualcamayo (Arenigiano-Llanvirniano) en el cerro Potrerillo, Precordillera de San Juan, Argentina. Boletín Academia Nacional de Ciencias 60 (3-4): 317-364. Córdoba.

Ortega, G.; Albanesi, G.L.; Frigerio, S. 2007. Graptoliteconodont biostratigraphy and biofacies of the Middle Ordovician Cerro Viejo succession, San Juan, Pre- 
cordillera, Argentina. Palaeogeography, Palaeoclimatology, Palaeoecology 245: 245-264.

Ortega, G.; Albanesi, G.L.; Banchig, A.L.; Peralta, G.L. 2008. High resolution conodont-graptolite biostratigraphy in the Middle-Upper Ordovician of the Sierra de La Invernada Formation (Central Precordillera, Argentina). Geologica Acta 6 (2): 161-180.

Ortega, G.; Albanesi, G.L.; Bejerman, A.; Voldman, G.G.; Banchig, A.L. 2010. Graptolite and conodont faunas from the Middle-Upper Ordovician Sierra de La Invernada Formation, Central Precordillera of San Juan, Argentina. In International Palaeontological Congress, No. 3. London.

Ottone, E.G.; Albanesi, G.L.; Ortega, G.; Holfeltz, G. 1999. Palynomorphs, conodonts and associated graptolites from the Ordovician Los Azules Formation, Central Precordillera, Argentina. Micropaleontology 45 (3): 225-250.

Patzkowsky, M.E. 1995. Gradient analysis of Middle Ordovician brachiopod biofacies: Biostratigraphic, biogeographic and macroevolutionary implications. Palaios 10: 154-179.

Peralta, S.H.; Albanesi, G.L.; Ortega, G. 2003. Ordovician and Silurian of the Precordillera, San Juan Province, Argentina. In Field Trip Guide, $9^{\text {th }}$ ISOS, International Graptolite Conference and Field Meeting of the Subcommission on Silurian Stratigraphy, No. 7 (Peralta, S.H.; Albanesi, G.L.; Ortega, G.; editors). Instituto Superior de Correlación Geológica (INSUGEO), Miscelánea 10: 7-149. Tucumán.

Pohler, S.M.L. 1994. Conodont biofacies of Lower to lower Middle Ordovician Mega- conglomerates, Cow Head Group, Western Newfoundland. Geological Survey of Canada, Bulletin 459: 1-71.

Pyle, L.J.; Barnes, C.R. 2002. Taxonomy, evolution, and biostratigraphy of conodonts from the Kechika Formation, Skoki Formation, and Road River Group (Upper Cambrian to Lower Silurian), Northeastern British Columbia. National Research Council of Canada Research Press: 227 p. Ottawa.

Pyle, L.J.; Barnes, C.R.; Ji, Z. 2003. Conodont fauna of the Outram, Skoki and Owen Creek formations (Lower to Middle Ordovician), Wilcox Pass, Alberta, Canada. Journal of Paleontology 77: 958-976.

Rasmussen, J.A. 2001. Conodont biostratigraphy and taxonomy of the Ordovician shelf margin deposits in the Scandinavian Caledonides. Fossils and Strata 48: 1-180.

Rasmussen, J.A.; Stouge, S. 1995. Late Arenig-early Llanvirn conodont biofacies across the Iapetus ocean.
In Ordovician Odyssey. Short Papers for the Seventh International Symposium on the Ordovician System (Cooper, J.D.; Droser, M.L.; Finney, S.C.; editors), Society for Sedimentary Geology, Pacific Section, Book 77: 443- 447. Fullerton.

Sarmiento, G.N. 1985. La Biozona de Amorphognathus variabilis-Eoplacognathus pseudoplanus (Conodonta), Llanvirniano inferior, en el flanco oriental de la sierra de Villicum. In Jornadas sobre Geología de la Precordillera, No. 1, Acta 1: 119-123. San Juan.

Sarmiento, G.N. 1991. Conodontos de la Zona E. suecicus (Llanvirniano inferior) en la sierra de Villicum, Precordillera de San Juan, Argentina. Revista Española de Micropaleontología 23: 113-132.

Sarmiento, G.N.; Rao, R.; Herrera, Z.A. 1986. Conodontes de la Formación San Juan aflorante en la Quebrada de Las Aguaditas, Departamento de Jáchal, Provincia de San Juan. In Congreso Argentino de Paleontología y Bioestratigrafía, No. 4, Actas 3: 213-217. Mendoza.

Schmitz, B.; Häggström, T.; Tassinari, M. 2003. Sediment-dispersed extraterrestrial chromite traces a major asteroid disruption event. Science 300 (5621): 961-4.

Schmitz, B.; Bergström, S.M.; Wang, X. 2010. The middle Darriwilian (Ordovician) $\delta^{13} \mathrm{C}$ excursion (MDICE) discovered in the Yangtze Platform succession in China; implications of its first recorded occurrence outside Baltoscandia. Journal of the Geological Society of London 167: 249-259.

Schmitz, B.; Harper, D.A.T.; Peucker-Ehrenbrink, B.; Stouge, S.; Alwmark, C.; Cronholm, A.; Bergström, S.M.; Tassinari, M.; Wang, X. 2008. Asteroid breakup linked to the Great Ordovician Biodiversification Event. Nature Geoscience 1 (1): 49-53.

Sergeeva, S.P. 1963. Conodonts from the Lower Ordovician in the Leningrad region. Akademia Nauk SSSR. Paleontologičeskij žurnal 1963: 93-108. Moskva.

Serra, F.; Feltes, N.A.; Albanesi, G.L. 2011. Yangtzeplacognathus crassus (Conodonta) en el intervalo de transición entre la Formación San Juan y unidades suprayacentes del Ordovícico Medio en la Precordillera Central de San Juan, Argentina. In Reunión Anual de Comunicaciones de la Asociación Paleontológica Argentina. Ameghiniana 48: R25. Luján.

Serra, F.; Feltes, N.A.; Albanesi, G.L. 2013. La Zona de Pygodus anserinus (Conodonta) en la Formación Las Aguaditas, Ordovícico Medio-Superior, de la Precordillera Central de San Juan, Argentina. In Reunión Anual de Comunicaciones de la Asociación Paleontológica Argentina 50: 46 (R). Córdoba. 
Serra, F.; Albanesi, G.L.; Ortega, G.; Bergström, S.M. 2015. Biostratigraphy and palaeoecology of MiddleLate Ordovician conodont and graptolite faunas of the Las Chacritas River section, Precordillera of San Juan, Argentina. Geological Magazine, First View: 1-17.

Stouge, S. 1984. Conodonts of the Middle Ordovician Table Head Formation, western Newfoundland. Fossils and Strata 16: 1-145.

Stouge, S. 2001: Conodont biostratigraphy of the Histiodella Bearing Strata (Whiterock-Middle Ordovician) of western Newfoundland. In Geological Association of Canada Meeting, Abstract 26: p. 146. St. John's.

Stouge, S. 2012. Middle Ordovician (late DapingianDarriwilian) conodonts from the Cow Head Group and Lower Head Formation, western Newfoundland, Canada. Canadian Journal of Earth Sciences 49 (1): 59-90.

Stouge, S.; Bagnoli, G. 1999. The suprageneric classification of some Ordovician prioniodontid conodonts. Bolletino della Societa Paleontologica Italiana 37: 145-158.

Stouge, S.S.; Nielsen, A.T. 2003. An integrated biostratigraphical analysis of the Volkhov-Kunda (Lower Ordovician) succession at Fågelsång, Scania. Bulletin of the Geological Society of Denmark 50: 75-94.

Stouge, S.; Zhao, Z. 2006. Middle Ordovician (Upper Darriwilian) conodont biostratigraphic correlation of western Newfoundland and the Kalpin area of the Tarim Region, Xinjiang Province, P.R. China. In Ancient life and modern approaches (Yang, Q.; Wang, L.; Weldon, E.A.; editors). International Palaeontological Congress, No. 2, University of Science and Technology of China Press, Abstracts: 321 p. China.

Stouge, S.S.; Du, P.; Zhao, Z. 2011. Middle Ordovician (Darriwilian) global conodont zonation based on the Dawangou and Saergan formations on the western Tarim region, Xinjiang Province, China. In Ordovician of the world (Gutiérrez-Marco, J.C.; Rábano, I.; García-Bellido, D.; editors). Publicaciones del Instituto Geológico y Minero de España, Series: Cuadernos del Museo Geominero 14: 581-586.

Sweet, W.C.; Bergström, S.M. 1974. Provincialism exhibited by Ordovician conodont faunas. Special Publication Society of Economic Paleontologists and Mineralogists 21: 189-202.

Sweet, W.C.; Bergström, S.M. 1984: Conodont provinces and biofacies of the Late Ordovician. Geological Society of America, Special Paper 196: 69-87.

Tolmacheva, T.Y.; Holmer, L.; Popov, L.; Gogin, I. 2004. Conodont biostratigraphy and faunal assemblages in radiolarian ribbon banded cherts of the Burubaital Formation, West Balkhash Region, Kazakhstan. Geological Magazine 141: 699-715.

Tolmacheva, T.Y.; Degtyarev, K.E.; Ryazantsev, A.V.; Nikitina, O.I. 2009. Conodonts from the upper Ordovician siliceous rocks of Central Kazakhstan. Paleontological Journal 43: 1498-1512.

Uyeno, T.T.; Barnes, C.R. 1970. Conodonts from the Lévis Formation (Zone D1) (Middle Ordovician), Lévis, Quebec. Contributions to Canadian Paleontology. Geological Survey of Canada, Bulletin 187: 99-123.

Viira, V. 1974. Ordovician conodonts of the east Baltic. Valgus Publishers: 142 p. Tallinn.

Viira, V. 2011. Lower and Middle Ordovician conodonts from the subsurface of SE Estonia and adjacent Russia. Estonian Journal of Earth Sciences 60: 1-21.

Viira, V.; Löfgren, A.; Mägi, S.; Wickström, J. 2001. An Early to Middle Ordovician succession of conodont faunas at Mäekalda, northern Estonia. Geological Magazine 138: 699-718.

Voldman, G.G.; Albanesi, G.L.; Do Campo, M. 2008. Conodont palaeothermometry of contact metamorphism in Middle Ordovician rocks from the Precordillera of western Argentina. Geological Magazine 145 (3): 1-14

Voldman, G.G.; Albanesi, G.L.; Ramos, V.A. 2009. Ordovician metamorphic event in the carbonate platform of the Argentine Precordillera: implications for the geotectonic evolution of the proto-Andean margin of Gondwana. Geology 37: 311-314.

Voldman, G.G.; Ortega, G.; Albanesi, G.L. 2013. Middle Ordovician conodonts and graptolites at Los Cauquenes Range, Central Precordillera of San Juan, Argentina. In Conodonts from the Andes (Albanesi, G.L.; Ortega, G.; editors). International Conodont Symposium, No. 3, Asociación Paleontológica Argentina, Special Publication 13: 117-121. Buenos Aires.

Wang, Z.H.; Bergström, S.M. 1999. Conodonts and their significance across the base of the Darriwilian Stage in Hubei and JCY area of Zhejiang and Jiangxi Province. Acta Micropalaeontologica Sinica 16 (4): 325-350.

Wang, Z.H.; Bergström, S.M.; Lane, H.R. 1996. Conodont provinces and biostratigraphy in Ordovician of China. Acta Palaeontologica Sinica 35 (1): 26-59.

Webby, B.D. 1984. Ordovician reefs and climate: a review. In Aspects of the Ordovician System (Bruton, D.L.; editor) Palaeontological Contributions from the University of Oslo 295: 89-100. Oslo.

Webby, B.D.; Cooper, R.A.; Bergström, S.M.; Paris, F. 2004. Stratigraphic framework and time slices. In The 
Great Ordovician Biodiversification Event (Webby, B.D.; Paris, F.; Droser, M.L.; Percival, I.G.; editors), Columbia University Press: 41-47. New York.

Wood, R. 1993. Nutrients, Predation and the History of reef building. Palaios 8 (6): 526-543. Tulsa.

Zhang, J.H. 1997. Lower Ordovician conodont Eoplacognathus crassus Chen and Zhang, 1993. GFF 119: 61-65.

Zhang, J.H. 1998a. Conodonts from the Guniutan Formation (Llanvirnian) in Hubei and Hunan Provinces, southcentral China. Stockholm Contributions in Geology 46: 1-161.

Zhang, J.H. 1998b. Middle Ordovician conodonts from the Atlantic Faunal Region and the evolution of key conodont genera. Meddelanden fran Stockholms Universitets institution för geologi och geokemi 298: 5-27.

Zhang, J.H. 1998c. The Ordovician conodont genus Pygodus. In Proceedings of the Sixth European Conodont Symposium (Szaniawski, H.; editor). Palaeontologia Polonica 58: 87-105.

Zhang, J.H. 1999. Review of the Ordovician conodont zonal index Eoplacognathus suecicus Bergström, 1971. Journal of Paleontology 73: 487-493.

Zhang, S.B.; Gao, Q.Q. 1991. Sinian to Permian stratigraphy and palaeontology of the Tarim Basin, Xinjiang. (II) Kalpin-Bachu Region. The Petroleum Industry Press: 329 p. Beijing.

Zhang, S.; Barnes, C.R. 2004. Late Cambrian and Early Ordovician conodont communities from platform and slope facies, western Newfoundland: a statistical approach. In The Palynology and Micropalaeontology of boundaries. (Beaudoin, A.B.; Head, M.J.; editors).
Geological Society, Special Publications 230: 47-72. London.

Zhao, Z.X.; Zhang, G.Z.; Xiao, J.N. 2000. Paleozoic stratigraphy and conodonts in Xinjiang. Petroleum Industry Press: 340 p. Beijing.

Zhen, Y.Y.; Percival, I.G. 2004. Darriwilian (Middle Ordovician) conodonts from the Weemalla Formation, south of Orange, New South Wales. Memoirs of the Association of Australasian Palaeontologists 30: 153-178.

Zhen, Y.Y.; Percival, I.G.; Webby, B.D. 2003. Early Ordovician conodonts from far western New South Wales, Australia. Records of the Australian Museum 55 (2): 169-220.

Zhen, Y.Y.; Percival, I.G.; Cooper, R.A.; Simes, J.E.; Wright, A.J. 2009. Darriwilian (Middle Ordovician) conodonts from Thompson Creek, Nelson Province, New Zealand. Memoirs of the Association of Australasian Palaeontologists 37: 25-53.

Zhen, Y.Y.; Wang, Z.H.; Zhang, Y.D.; Bergström, S.M.; Percival, I.G.; Chen, J.F. 2011a. Middle to Late Ordovician (Darriwilian-Sandbian) conodonts from the Dawangou section, Kalpin area of the Tarim Basin, northwestern China. Records of the Australian Museum 63 (3): 203-266.

Zhen, Y.Y.; Cooper, R.A.; Simes, J.E.; Percival, I.G. 2011 b. Darriwilian (Middle Ordovician) conodonts from the Maruia-Springs Junction area, New Zealand. Memoirs of the Association of Australasian Palaeontologists 42: 285-319.

Zhylkaidarov, A. 1998. Conodonts from Ordovician ophiolites of central Kazakhstan. Acta Palaeontologica Polonica 43: 1-5348.

Manuscript received: July 16, 2015; revised/accepted: November 11, 2015; available online: November 11, 2015. 